Faculdade de Economia da Universidade de Coimbra

Grupo de Estudos Monetários e Financeiros (GEMF)

Av. Dias da Silva, 165 - 3004-512 COIMBRA, PORTUGAL

http://www4.fe.uc.pt/gemf/ - gemf@ sonata.fe.uc.pt

CARLOS FONSECA MARINHEIRO

RICARDIAN EQUIVALENCE: AN

EMPIRICAL APPLICATION TO THE

PORTUGUESE ECONOMY

ESTUDOS DO GEMF

N. ${ }^{\circ} 11$

2001

PUBLICAÇÃO CO-FINANCIADA PELA

FUNDAÇÃO PARA A CIÊNCIA E TECNOLOGIA 


\title{
RICARDIAN EQUIVALENCE: AN EMPIRICAL APPLICATION TO THE PORTUGUESE ECONOMY
}

\author{
Carlos Fonseca Marinheiro* \\ marinheiro@fe.uc.pt \\ http://www4.fe.uc.pt/carlosm \\ (Faculty of Economics of the University of Coimbra \\ and Katholieke Universiteit Leuven)
}

June 2001

\begin{abstract}
It is the purpose of this paper to focus on the consequences of the Ricardian offset to the conduct of stabilising fiscal policies. If equivalence prevails there is no scope for effective stabilising fiscal policies. A review of the theoretical requirements of Ricardian equivalence reveals that they are not likely to be fulfilled in practice. However, the brief survey of the empirical applications shows that the published empirical evidence is inconclusive. An empirical application for the Portuguese economy is carried out. The tests are based on reduced-form consumption functions and on the Euler equation approach. The overall results are ambiguous.
\end{abstract}

\footnotetext{
* Correspondence to: Faculdade de Economia, Av. Dias da Silva 165, P-3004-512 Coimbra, Portugal. Email: marinheiro@fe.uc.pt. A previous version of this paper was presented at a Katholieke Universiteit Leuven Workshop in International Economics. I am grateful for helpful comments to a number of participants in that workshop, in particular my supervisor Paul De Grauwe and Hans Dewachter. As usually any remaining mistakes are my responsibility. This research received financial support from the FCT, under the Subprogramme Science and Technology of the $2^{\text {nd }}$ Community Support Framework to Portugal.
} 


\section{Contents}

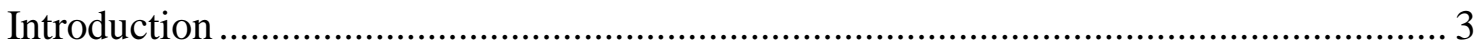

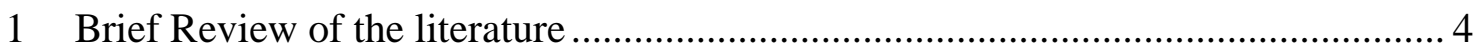

1.1 Theoretical requirements of Ricardian equivalence .....................................4

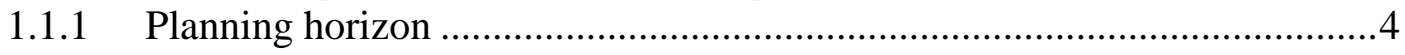

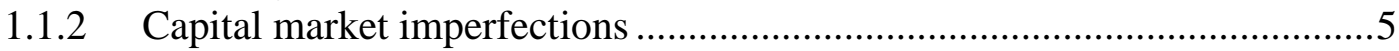

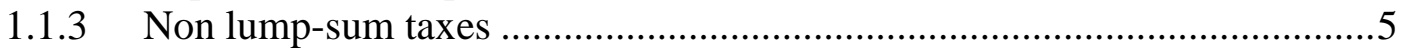

1.1.4 Excess sensitivity of consumption to current income ...............................6

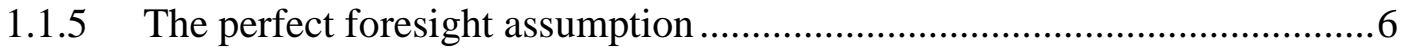

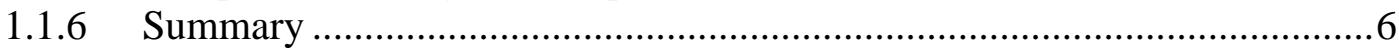

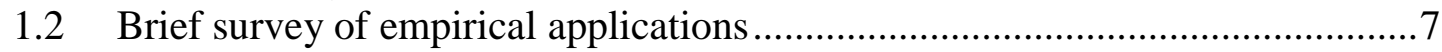

1.2.1 Reduced-form (structural) consumption functions ....................................

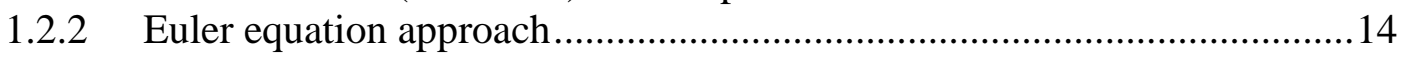

2 Empirical application to the Portuguese economy ............................................... 21

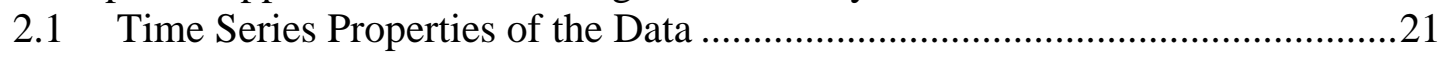

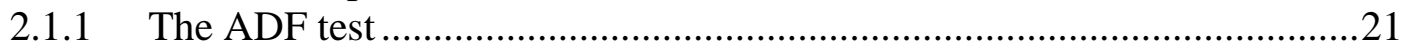

2.2 Reduced-form (structural) consumption functions .......................................23

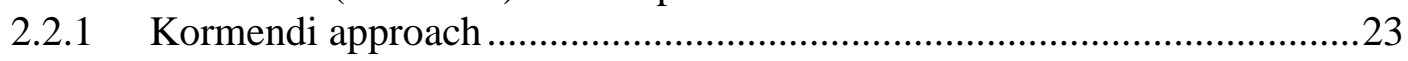

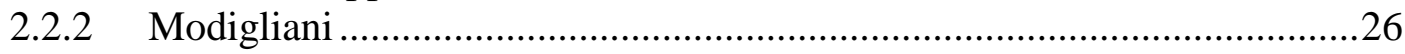

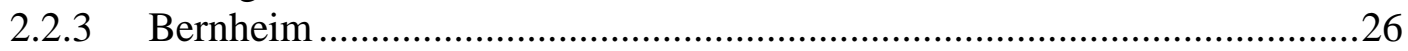

2.2.4 Pereleman and Pestieau (1993) approach .............................................26

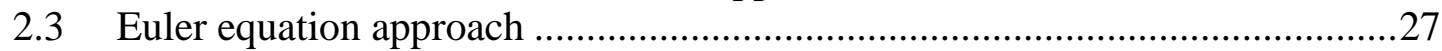

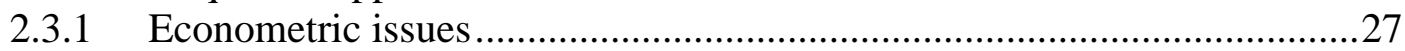

2.3.2 Results of the generalised permanent income model ...............................29

2.3.3 Results of the generalised permanent income model and the excess sensitivity hypothesis .........................................................................30

2.3.4 Results of the permanent income model with a consolidated government

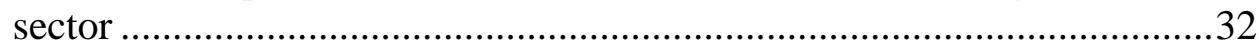

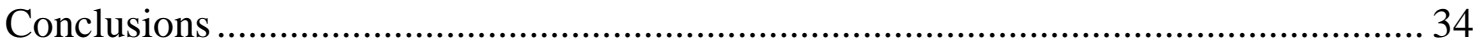

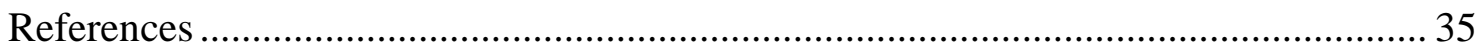

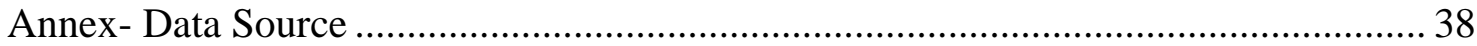

Appendix- A tentative construction of a proxy for the wealth variable for the Portuguese economy .................................................................................... 38 


\section{Introduction}

The fiscal policy may be used with a stabilising role if the government finance decisions are able to influence private consumption (i.e., aggregate demand) and saving. This influence depends on the degree to which consumers treat government debt as net wealth.

According to the Keynesian consensus consumers treat government debt as net wealth. Therefore, a substitution of debt for taxes has a positive influence on private consumption and aggregate demand. However, the consequent decrease in private and national saving, implies an increase in the real interest rate, which crowds out private investment. The reduction in the capital accumulation then leads to a reduction of the long-term growth prospects of the economy. This negative long-run effect offsets some of the positive short-term effects of the government deficit.

The Ricardian thesis has a complete opposite view. It states that, for a given expenditure path, substitution of debt for taxes has no effect on aggregate demand nor in interest rates. The government's inter-temporal budget constraint implies that, for an unaltered level of government outlays, a tax cut now implies a tax increase in the future. As borrowing only postpone taxes for the future, consumers, who are simultaneously taxpayers, anticipating the increase in future taxes, do not consider the current tax cut and the consequent increase in disposable income as being permanent. Their inter-temporal budget restriction is left unaltered. Therefore, consumption is also unaffected. The increased disposable income is entirely saved.

Under Ricardian equivalence consumers react to the tax cut by increasing their savings. These increased private savings are applied to buy the newly issued bonds, ${ }^{1}$ which enable consumers to have the resources to pay the increased future taxes necessary to repay the debt in the future. Therefore, as private saving increases by the same amount as does the budget deficit, the national saving remains unaffected, which leaves the interest rate unaltered. In an open economy, the deficit has no effect on the current account balance because the increase in private saving it originates is enough to avoid the need of external financing. Consequently, the deficit does not crowd out capital, nor deteriorates the current account balance. The public debt does not affect private sector wealth. Or in other words, consumers do not consider government bonds as net wealth. Therefore, and for a given expenditure path, it is equivalent financing the public outlays by debt or taxation. The timing of taxes has no effect on the private consumption.

The policy implications of the Ricardian equivalence view are rather radical: as a deficit-financed tax cut has no impact on private consumption, even in the short-run the government cannot stabilise the economy. In a recession, a tax cut with the purpose of inducing an increase in consumption spending is an effort completely futile when the equivalence holds.

We will proceed by reviewing the theoretical requirements of Ricardian equivalence. Then we will give a brief survey of the most relevant empirical studies on equivalence. Finally, and taking as a point of departure those studies, an empirical application to the

\footnotetext{
${ }^{1}$ Ricardian equivalence implies a "Say's Law" for government debt: the demand for titles increase by the same amount as does the supply.
} 
Portuguese economy is performed. The tests are based on reduced-form consumption functions and on the Euler equation approach.

In order to carry the first block of tests a measure of the capital stock is required. As there are no official estimates for the Portuguese economy an attempt is made in the Annex to find a proxy. That attempt is based on the work of Santos (1984).

\section{Brief Review of the literature}

Since the publication in 1974 of Barro's (1974) seminal paper on the equivalence proposition there has been published an extensive amount of literature on the subject. The purpose of this paper is just to review some of the most important empirical studies. However, in order to provide some theoretical background we will start by examining the theoretical requirements for the verification of the equivalence.

\subsection{Theoretical requirements of Ricardian equivalence}

In order equivalence to hold, a large number of requirements must be fulfilled. ${ }^{2}$ It is necessary that:

1. government consumption stays unaltered at its initial level;

2. the service of the debt (interests and repayment of the principal) must be financed by taxes levied in later periods (there are no Ponzi games);

3. consumers have the same planning horizon as the government;

4. taxes are lump sum;

5. capital markets are perfect, and individuals may borrow and lend at the same rate as the government and with no borrowing constraints;

6. there is no uncertainty about future income;

7. and individuals fully anticipate the future-period tax-liabilities that are implicit in the debt issue.

When those assumptions do not hold the Ricardian equivalence breaks down.

\subsubsection{Planning horizon}

In order Ricardian equivalence to hold, the individual must have the same time horizon as the government, which is usually assumed to be infinite. If that is not true, i.e. if an individual has a shorter time horizon than the government, the issue of new debt to be repaid in the future, after the probable death of that individual, will imply an increase in the net wealth of that individual as he or she will not have to contribute for the repayment of the principal. Nevertheless, this problem of finite life spans was solved by Barro's (1974) seminal paper assuming the existence of an operational bequest motive.

A series of individuals with finite lifetimes will act as if they were a single household living forever if they are linked to future generations through a chain of altruistic bequests. Each individual cares about the well-being of his (or her) descendants. In this

${ }^{2}$ Vide for instance Brennan and Buchanan (1986), and Bernheim (1987a). 
case the individual will not react to a tax cut by increasing its consumption, which would ultimately decrease the well-being of his descendants. Instead he will buy the bond and pass it, together with the accumulated interest, on to the next generation.

Only if bequests are non-operative there will be an increase in consumption. For instance, that is the case of childless families ${ }^{3}$ or of families that do not care about their children. On the other hand it is argued that this possible failure of the equivalence is not quantitatively very important. Poterba and Summers (1987) argue that lifetimes are long enough to enable the Ricardian equivalence to be a good approximation of the reality, if there are no other failures on its assumptions. Two reasons lead to that conclusion. Firstly, because the large part of the present value of the taxes associated with the bond issues are levied during the lifetimes of the individuals alive at the time of the issue. Secondly, long lifetimes imply that an increase in wealth, originated by the bond issue, has only a small effect on current consumption.

\subsubsection{Capital market imperfections}

The existence of capital markets imperfections, such as liquidity constraints ${ }^{4}$ leads to departures from equivalence. According to Hayashi (1987: 92) "consumers are liquidity constrained if they face quantity constraints on the amount of borrowing (credit rationing) or if the loan rates available to them are higher than the rate at which they could lend (differential interest rates)". When subject to liquidity constraints a household is not able to smooth out consumption over their entire lifetime. The consumption-planning horizon is shorter than the lifetimes of the individuals. Therefore, they will not be indifferent to an opportunity to differ their tax burden.

Lets assume a household that expects a future income higher than its current income. Their members would like to increase their current consumption. However, they face liquidity constraints that prevent them from obtaining the necessary funds in the capital market at the same interest rate as the government. In this case the bond issue will matter. When issuing a bond the government is in fact borrowing on the household's behalf: it gives the household a reduction in current taxes that will be repaid by higher taxes in the future. The cost of those funds is the government's interest rate. Therefore, this household will react to the tax cut by increasing its consumption.

On the other hand, an increase in the deficit implies an increase in the present value of future taxes, which reduces this household's collateral. This fact may induce rational private lenders to respond to the bond issue by reducing their credit to this household. This mitigates the effects of the bond issue on current consumption.

\subsubsection{Non lump-sum taxes}

Ricardian equivalence assumes lump-sum taxes. However, in reality taxes are not lump-sum, they are a fraction of income. The tax liability is large if future income is high, and low if future income is low. This reduces the uncertainty about the household's lifetime resources, which may lead to an increase in current consumption

\footnotetext{
${ }^{3}$ Seater (1993: 158) estimates the childless families to be around $20 \%$ of households in the U.S.

4 Also according to Seater (1993: 159) liquidity constrained households represent 12 to $18 \%$ of households in the U.S.
} 
(Romer, 1996: 70). The increase in future taxes leads also to an attempt to transfer income from the future to the present, reducing saving and capital accumulation.

Non lump-sum taxes may also interact with liquidity constraints causing large departures from equivalence (Bernheim, 1987b). If we assume that the more liquidityconstrained households are the ones that have low income, ${ }^{5}$ then their share of the tax liability associated with the bond issue is small. Therefore, their collateral and their probability of obtaining funds in the market is relatively unaffected by the increase in taxes. Thus, a tax cut will have a positive effect on their consumption.

According to the Keynesian view the temporal discount rate for the future taxes is the one that is used to borrow from the future income. As the future income is more uncertain than the current one, this interest rate is higher than the interest on government debt. Thus, the present value of future taxes is less than the issued debt. If true, a bond-financed-tax-cut has a positive net wealth effect even when the increase in future taxes is fully anticipated by the taxpayers.

\subsubsection{Excess sensitivity of consumption to current income}

The Ricardian equivalence will fail if individuals do not optimise consumption fully over long horizons (Romer, 1996: 71). When the consumers put a great weight on current after-tax income, an increase in current consumption is expected as a response to a bond-financed tax-cut even if their lifetime budget constraints are not affected.

The consumption function has been found to be more sensitive to fluctuations in current income than it is forecasted by the permanent-income consumption model, as a result of the presence of non-optimising rule-of-thumb consumers (Brunila, 1997).

\subsubsection{The perfect foresight assumption}

The Ricardian equivalence is based on the perfect foresight assumption. This is a very strong assumption, which is difficult to sustain in an increasing uncertain world (De Grauwe, 1996: 165-7). When this assumption is relaxed and an uncertain environment with inflation risk and default (or solvency) risk emerges, non-equivalence results do arise.

As (Ricardo, 1820: 186-7) recognised the reasoning of the equivalence is logical but "... the people who pay the taxes never so estimate them, and therefore do not manage their private affairs accordingly".

\subsubsection{Summary}

In order Ricardian equivalence to hold a large number of assumptions should be fulfilled. However, theoretical restrictiveness of Ricardian equivalence does not constitute a practical refutation of its validity. As Barro (1989: 48) put it: "It is easy on theoretical grounds to raise points that invalidate strict Ricardian equivalence.

\footnotetext{
${ }^{5}$ This assumption is not always true. Just think about a recent graduate student that expects a higher future income than its current level, but is unable to borrow in the capital markets.
} 
Nevertheless, it may still be that the Ricardian view provides a useful framework for assessing the first-order effects of fiscal policy. Furthermore, it is unclear that the standard analysis offers a more accurate guide. For this reasons it is especially important to examine empirical evidence". That is the purpose of the next section.

\subsection{Brief survey of empirical applications}

There are broadly two classes of tests on the validity of Ricardian equivalence. One set of tests is based on the consumption function and others test the effects of deficits on interest rates.

The first type of tests try to evaluate whether increases in government debt are perceived as net wealth by individuals, and originate increases in private consumption. The second type of tests evaluates whether deficits lead to an increase in interest rates. In this latter case there is the problem of discriminating between the Ricardian equivalence and the perfect capital markets hypothesis for an open economy. In an open economy, even if consumers are not Ricardian, and increase their consumption in response to a budget deficit, the interest rate may remain unchanged. That is the case when international capital flows are supposed to equalise the interest rate across countries. A budget deficit may be financed by an inflow of capital leaving the domestic interest rate unaltered. However, in this case it would originate a current account deficit, leading to the so-called twin-deficit phenomena, if Ricardian equivalence does not hold.

There are some serious econometric problems in both type of tests, namely the endogeneity $^{6}$ and identification ${ }^{7}$ problems, besides some measurement problems ${ }^{8}$ (Bernheim, 1987a). Despite this they should be carried out.

This paper will be focused on the consumption function studies. These may be divided in two categories: the reduced-form consumption functions and Euler equationspecification. Some authors argue that reduced-form equations are biased, as they are not the result of an optimisation problem, and do not always nest the Ricardian equivalence and alternative hypothesis. ${ }^{9}$ However, as Bernheim (1987a: 314) points out "with the right income and wealth variables, and interest rates, (including expectations of future incomes and interest rates) "structural" consumption functions are completely consistent with the Euler equation approach under rational expectations". Moreover, the Euler equation specification is often rejected by the data due to reasons unrelated with Ricardian equivalence. As the Ricardian equivalence could be considered an

\footnotetext{
${ }^{6}$ The deficit, public consumption, private consumption, income and interest rate may be determined simultaneously. A possible solution for the endogeneity problem is the use of instrumental variables. However, sometimes the used instruments are not really exogenous.

${ }^{7}$ It is very difficult to distinguish between the effects of different fiscal policy variables. Each of the public consumption, transfers, taxes, deficits and debt variables has an independent effect on economic activity. Yet the first four variables plus interest on debt sum to zero, which gives rise to the identification problem (see Bernheim, 1987a).

${ }^{8}$ As examples of measurement problems there are the use of nominal versus pair values for privately held debt and the treatment of consumer durable expenses in the measurement of consumption.

9 Flavin (1987: 208) argues that the non-rational expectation aggregate consumption function is fundamentally inconsistent with the Ricardian equivalence hypothesis. In order equivalence to hold, the agents should maximise their inter-temporal utility and form expectations rationally. Consequently, according to the author, an Euler equation specification should be used to test Ricardian equivalence.
} 
extension of the permanent income-life-cycle hypothesis, a rejection of this hypothesis by the data leads to the non-validity of the Euler equation.

As mentioned above, the excess sensitivity of consumption to current income is one of the reasons for the lack of data support for the permanent income hypothesis. Furthermore, in order to derive the Euler equation a substantial number of restrictive assumptions must be made. For instance, if we assume future income to be uncertain it is not possible to obtain a closed-form solution for consumption from the Euler equation (Seater, 1993). It is also impossible to derive a consumption function from an optimising model in the presence of stochastic real interest rate, so it is necessary to assume a constant, and given, interest rate. On the other hand, the Euler equation approach has the advantage of being directly based on the inter-temporal optimisation problem.

\subsubsection{Reduced-form (structural) consumption functions}

We will try in this section to do a very brief survey of the numerous studies published on this subject. The survey will be centred in the most relevant and recent ones. For more detailed surveys see Bernheim (1987a) and Seater (1993).

\subsubsection{Kormendi's (1983) study}

In the words of Feldstein and Elmendorf (1990: 589) the empirical work of Kormendi (1983) "is the strongest direct evidence in favour of Ricardian equivalence". It was also given a central position in Seater's (1993) survey of the equivalence debate.

Kormendi (1983) argues for a "consolidated approach" to consumer behaviour to substitute the "standard approach". The standard (Keynesian) approach considers consumption as a function of disposable income and uses a concept of private wealth that includes government debt. Thus, it makes the implicit assumption that the private sector is too myopic to account for the effects of government debt on future taxes. Therefore, this implies that the private sector's perceptions are not rational.

Kormendi's consolidated approach is the result of modelling private consumption based on a rational consolidation of the public and private sectors. Consumption is a function of aggregate income, government spending, wealth and transfers. When the consolidated approach is valid Ricardian equivalence holds.

To confront both approaches Kormendi (1983) estimates an "augmented" private consumption function:

$$
\begin{aligned}
\Delta \mathrm{PC}_{\mathrm{t}}= & \mathrm{a}_{0}+\mathrm{a}_{11} \Delta \mathrm{Y}_{\mathrm{t}}+\mathrm{a}_{12} \Delta \mathrm{Y}_{\mathrm{t}-1}+\mathrm{a}_{2} \Delta \mathrm{GS}_{\mathrm{t}}+\mathrm{a}_{3} \Delta \mathrm{W}_{\mathrm{t}}+\mathrm{a}_{4} \Delta \mathrm{TR}_{\mathrm{t}}+\mathrm{a}_{5} \Delta \mathrm{TX}_{\mathrm{t}}+\mathrm{a}_{6} \Delta \mathrm{RE}_{\mathrm{t}} \\
& +\mathrm{a}_{7} \Delta \mathrm{GINT}_{\mathrm{t}}+\mathrm{a}_{8} \Delta \mathrm{GB}_{\mathrm{t}}+\mathrm{u}_{\mathrm{t}}
\end{aligned}
$$

where $\mathrm{PC}$ is private consumption, $\mathrm{Y}$ is net national product, GS is government spending on goods and services, $\mathrm{W}$ is human and non-human wealth, TR is government's transfers to individuals, TX is government tax receipts, RE is corporate retained earnings, GINT is government interest payments on its outstandind debt, GB is the market value of the outstanding government debt. All variables are measured in 
real, per capita terms, and $\Delta$ is the first-difference operator. ${ }^{10}$ Lagged real income is included to reflect any incremental information it may contain as proxy to permanent income. All variables, but GS, are deflated by the implicit price deflator for the net national product.

$\mathrm{PC}$ is consumer expenditures on nondurables and services plus an imputed service flow of the stock of consumer durables, more precisely $30 \%$ of the total net stock of durable goods owned by consumers plus $10 \%$ of the current expenses on consumer durables. Graham (1992) argues that the use of alternative consumption measures is not innocuous for the testing of Ricardian equivalence.

The standard and consolidated approaches imply different restrictions to equation (1). According to the standard approach the private sector ignores the government spending, implying $\mathrm{a}_{2}=0$; private consumption is assumed to depend upon permanent personal disposable income, which implies $a_{5}<0$ and $a_{6}<0$, and $a_{7}>0$. Government debt has a positive wealth effect, so $a_{8}>0 .^{11}$

Under the consolidated approach the government spending affects consumption negatively, implying $\mathrm{a}_{2}<0$; the choice of tax versus debt finance has no effect on private consumption, thus $\mathrm{a}_{5}=0$; retained earnings are perceived as private saving, which accrue to the individuals through their ownership in corporations, implying $\mathrm{a}_{6}=0$; government debt and government interest payments on outstanding debt have no effect on private consumption, which implies $\mathrm{a}_{7}=\mathrm{a}_{8}=0$.

To sum up, the standard approach implies $a_{2}=0,\left(a_{5}, a_{6}\right)<0, a_{7}>0$, and $a_{8}=a_{3}>0 .{ }^{12}$ The consolidated approach implies $\mathrm{a}_{2}<0$ and $\mathrm{a}_{5}=\mathrm{a}_{6}=\mathrm{a}_{7}=\mathrm{a}_{8}=0$.

Kormendi (1983) has the controversial opinion that the coefficient on transfers $\left(a_{4}\right)$ might be larger than the coefficient on current income $\left(\mathrm{a}_{11}\right)$ because those receiving the transfers are likely to have higher marginal propensity to consume than those receiving income from other sources.

The equation was estimated using annual data for the 1931-1976 period. Kormendi's (1993) results were favourable to the consolidated approach. The estimation results were very controversial and gave rise to an inflamed discussion, not finished yet. Modigliani and Sterling (1986) criticise the low value of the estimated coefficient for income and the high value of the coefficient on transfers. An increase in transfers may be seen as a negative tax, therefore according to Ricardian equivalence transfers should not have any effect on private consumption. ${ }^{13}$ They criticise also the absence of long distributed lags. The Kormendi's study was further criticised for problems of data construction, like the use of inappropriate deflators. It was also argued that the Second

\footnotetext{
${ }^{10}$ The first-difference form is used because of the presence of unit roots and lack of evidence that consumption is co-integrated with the right-hand side variables (Kormendi and Meguire, 1990).

${ }^{11}$ It is possible to have $a_{8}<a_{3}$ if the yield on government debt is less than the yield on private wealth, reflecting a lower risk premium.

${ }^{12}$ A more restrictive view of the standard approach implies $a_{11}=a_{4}=-a_{5}=-a_{6}=a_{7}, a_{2}=0, a_{8}>0$ (Graham, 1995: 1349).

13 According to Modigliani and Sterling (1986) the transfers are a good signal of a component of permanent income -social security wealth- that are more certain than labour income, which could be decreased unexpectedly.
} 
World War period and the great depression period should be excluded from the sample period. $^{14}$

Feldstein and Elmendorf (1990) suggest the use of a ratio specification in order to reduce the problem of collinearity among net national product and the fiscal variables. These authors suggest as well the use of instrumental variable estimation to reduce the problem of endogeneity of net national product and of the fiscal variables. Nevertheless, it is very problematic to find good exogenous instruments, i.e. variables that are not correlated with the current disturbance to consumer spending but highly correlated with the endogenous explanatory variables. Feldstein and Elmendorf (1990) use the past values of the endogenous variables lagged 2, 3 and 4 years. Their results are against Ricardian equivalence. For another example of the large literature originated by Kormendi's study see, for instance, Barth et al. (1986).

More recently Graham (1995) criticised Kormendi and Meguire (1990) for the augmented equation that nests the standard and consolidated approach not being sufficiently general. It restricts income from labour and income from capital to enter the consumption function with the same coefficient. ${ }^{15}$ It argues as well that the market value of non-human wealth reflects the present value of after-tax stream of income from that wealth. Therefore, if non-human wealth is well measured then taxes on capital income should be excluded from the tax variable.

Kormendi and Meguire (1995) maintain that "the first-order effect of the public sector on private sector behaviour derives from the level and composition of government outlays". They also maintain that the estimation results for the 1930 to 1991 period are fully consistent with the consolidated approach. The opposite conclusion of Graham (1995) is attributed to a "flawed measure of labour income". Moreover, according to the authors, a full empirical distribution of estimations computed from a set of 128 specifications fully supports the consolidated approach.

\subsubsection{Modigliani and Sterling (1986)}

Modigliani and Sterling (1986) propose an alternative way of testing the Ricardian equivalence more in light with the life-cycle theory. Assuming expectations can be modelled as a distributed lag of past variables, the proposed consumption function is:

$$
\mathrm{C}_{\mathrm{t}}=\mathrm{a}+\mathrm{b}_{0} \mathrm{~W}_{\mathrm{t}}+\mathrm{b}_{1} \mathrm{~GB}_{\mathrm{t}}+\sum_{\mathrm{i}=1}^{\mathrm{L}} \mathrm{c}_{\mathrm{i}}\left(\mathrm{Y}_{\mathrm{t}-\mathrm{i}}-\mathrm{TL}_{\mathrm{t}-\mathrm{i}}\right)+\sum_{\mathrm{i}=1}^{\mathrm{L}} \mathrm{d}_{\mathrm{i}} \operatorname{Def}_{\mathrm{t}-\mathrm{i}}+\mathrm{u}_{\mathrm{t}}
$$

where $\mathrm{L}=5$; TL stands for taxes net of transfers, including government net real ex-post domestic interest payments; Def is the government budget deficit defined as government expenditure minus net taxes.

\footnotetext{
${ }^{14}$ According to some authors, the war rationing and the patriotic appeals to saving have leaded to an abnormally high savings rate while simultaneously the government ran an enormous budget deficit. This biases the results in a pro-equivalence way.

${ }^{15}$ Another critic of Graham (1995) was that state and federal fiscal variables enter the equation with the same coefficient, which biases the results in favour of the equivalence. The argument is that $1 / 4$ of the revenue of the U.S. states comes from the consumption sales taxes and many states are constrained by balanced budget rules. Therefore when consumption decreases, the tax revenues also decrease, which leads to a nearly perfect positive correlation with consumer expenditures.
} 
For the life-cycle theory $b_{1}=0$ and $\Sigma d_{i}=0$. For Ricardian equivalence $b_{1}=-b_{0}$ and $\Sigma \mathrm{d}_{\mathrm{i}}=-\Sigma \mathrm{c}_{\mathrm{i}}$. The estimated results were against Ricardian equivalence.

\subsubsection{Bernheim (1987a)}

In a survey paper Bernheim (1987a) synthesises in two equations a great number of consumer studies. The first is:

$\mathrm{C}_{\mathrm{t}}=\alpha_{0}+\alpha_{1}\left(\mathrm{Y}_{\mathrm{t}}-\mathrm{TX}_{\mathrm{t}}\right)+\alpha_{2}\left(\mathrm{TX}_{\mathrm{t}}-\mathrm{G}_{\mathrm{t}}-\mathrm{r}_{\mathrm{r}} \mathrm{GB}_{\mathrm{t}}\right)+\alpha_{3} \mathrm{G}_{\mathrm{t}}+\alpha_{4} \mathrm{~GB}_{\mathrm{t}}+\alpha_{5} \mathrm{~W}_{\mathrm{t}}+\mathrm{X}_{\mathrm{t}} \bar{\alpha}+\xi_{\mathrm{t}}$

Where $\mathrm{C}$ denotes real consumption per capita, $\mathrm{X}$ is a vector of other exogenous variables and $\mathrm{r}$ is the interest rate; all other letters have the same meaning as before (so that $\mathrm{Y}-\mathrm{TX}$ is disposable income and $\mathrm{T}-\mathrm{G}-\mathrm{rGB}$ is government surplus).

The second equation is:

$$
C_{t}=\beta_{0}+\beta_{1} Y_{t}+\beta_{2}\left(T X_{t}-G_{t}-r_{r} G_{t}\right)+\beta_{3} G_{t}+\beta_{4} G_{t}+\beta_{5} W_{t}+X_{t} \bar{\beta}+\zeta_{t}
$$

The pure Keynesian view implies $\alpha_{2}=0$ and $\left(\beta_{2}=-\beta_{1}\right) ; \alpha_{2}=\alpha_{1}\left(\beta_{2}=0\right)$ represents Ricardian equivalence; and $\alpha_{1}-\alpha_{2}\left(\beta_{2}\right)$ measures the effect on current consumption of a $\$ 1$ tax-for-debt-swap.

In the context of international comparisons Bernheim (1987a) proposes the following specification form based on equation (4), in ratio form:

$$
\frac{\mathrm{C}}{\mathrm{Y}}=\beta_{1}+\beta_{2} \frac{\mathrm{Def}}{\mathrm{Y}}+\beta_{3} \frac{\mathrm{G}}{\mathrm{Y}}+\beta_{4} \frac{\mathrm{GB}}{\mathrm{Y}}+\beta_{5} \frac{\mathrm{W}}{\mathrm{Y}}+\beta_{6} \dot{\mathrm{Y}}+\beta_{7} \mathrm{Pop}+\varepsilon
$$

Where $\dot{Y}$ stands for real GDP growth, and Póp for population growth, GB is domestically held government debt. The equation (4) was modified by dropping the intercept $\left(\beta_{1}\right.$ is the intercept of the income variable in the previous consumption regression) assuming implicitly that the utility is homothetic. The division by the GNP enables an adjustment for heteroscedasticity, and avoids the need to convert the values to a common currency through exchange rates. In his estimation $\mathrm{W}$ was omitted due to lack of data ${ }^{16}$. The last two variables were used as socio-economic indicators. The measure of the deficit used is the current deficit of consolidated central government, adjusted for inflationary erosion of the real value of outstanding debt.

The equation above was estimated using 12-year and 6-year averages, in levels and in first-difference form. Bernheim's (1987a) conclusion was against Ricardian equivalence: the budget deficit stimulates consumption by about $\$ 0.40$ in the dollar.

\footnotetext{
${ }^{16}$ Money plus quasi-money were used as proxy for wealth but were found never significant and with the wrong sign.
} 


\subsubsection{Pereleman and Pestieau (1993)}

Another interesting study is that of Pereleman and Pestieau (1993). They estimate the following consumption function:

$\mathrm{C}=\alpha_{0}+\alpha_{1}(\mathrm{Y}-\mathrm{TX})+\alpha_{2} \mathrm{DEF}+\alpha_{3} \mathrm{~W}+\alpha_{4} \mathrm{~GB}+\varepsilon_{\mathrm{t}}$

The Ricardian equivalence is interpreted as implying $\alpha_{1}+\alpha_{2}=0$ and $\alpha_{4}=0$, meaning that a $\$ 1$ tax for debt swap has no effect on current consumption. On the contrary, the pure Keynesian view implies that $\alpha_{2}=0$. Their results, for eighteen OECD countries, reject both the pure equivalence and the pure Keynesian view. The deficit coefficient was found significantly negative. The value of $-\left(\alpha_{1}+\alpha_{2}\right)$ is interpreted as an index of equivalence. The larger that value the closer we are of full neutrality of fiscal policy, for a given expenditure path.

\subsubsection{Cardia (1997)}

A different perspective arises from the work of Cardia (1997). The author replicates standard consumption tests of Ricardian equivalence using series generated from the Blanchard's (1985) model that nests Ricardian equivalence with a non-Ricardian alternative. The failure of Ricardian equivalence in this alternative is due to finite horizons and/or distortionary taxation.

The simulated data gives rise to unstable estimations for the coefficients of the tax revenues and debt variables. The results lead the author to conclude that much of the conflicting empirical evidence may be due to a weakness in the statistical tests performed. One of the most serious problems that were "diagnosed" was the endogeneity of income. This endogeneity along with distortionary taxation biases the coefficient of taxes towards zero. For instance, an increase in the labour tax depresses consumption, work effort and output. As consumption and income are positively correlated, the indirect effects of taxes on consumption through the decrease in output are not captured. The author then suggests the use of a proxy for output, like productivity. Another solution might be the use of the instrumental variables estimation method, but there is the problem of the lack of good instruments.

All in all, her study concluded for the weakness of the usual tests. Moreover, these tests were found as not being able to discriminate between a good and a poor approximation to Ricardian equivalence.

\subsubsection{Leachman (1996)}

Using a multi-co-integration approach, Leachman (1996) concludes that saving and public debt, in the U.S., could be weakly co-integrated and with very slow speeds of adjustment.

Moreover, he concludes that the invalidity of Ricardian equivalence might not be the result of a failure of private-sector rational expectations but due to a public sector failure to incorporate its inter-temporal budget constraint: the debt levels and taxes were found as not being co-integrated. 


\subsubsection{Other recommendations and studies}

Seater (1993) argues against the use of disposable income as the income variable for testing Ricardian equivalence, because it constrains the coefficient on total income and taxes to have the same absolute value. These types of restrictions should not be imposed without testing. He also supports that all consumption functions should include government spending as an independent variable to control for changes in that variable. $^{17}$

It would also be important to include the marginal tax rate as an independent variable in the consumption function. However, due to lack of data this is seldom done, but its omission is not severe (Seater, 1993: 172).

Other variables that are suggested to be included in the consumption studies are the changes in the price level and changes in the unemployment rate. The latter could be used as a proxy to real income uncertainty.

Another suggestion by Seater (1993) is the decomposition of income and government spending in its permanent and transitory components. Seater and Mariano (1985) have done it using the Beveridge-Nelson method to decompose the variables. However, there is no evident way for decomposing those variables. Every method has its own drawbacks.

Another example of such studies is that of Cebula et al. (1996). The authors have dichotomised the deficit into structural and cyclical components, using the official published data for the U.S. The structural deficit is the result of what the deficit would be after the removal of all automatic responses of receipts and outlays to economic fluctuations. According to the authors, it reflects the planned or expected deficit. The cyclical deficit may be regarded as the unexpected deficit. The estimated equation is:

$\mathrm{PS} / \mathrm{Y}=\beta_{0}+\beta_{1} \mathrm{CD} / \mathrm{Y}+\beta_{2} \mathrm{SD} / \mathrm{Y}+\beta_{3} \Delta \mathrm{YD}+\beta_{4} \mathrm{~A}_{25}+\beta_{5} \mathrm{~A}_{35}+\beta_{6} \mathrm{~A}_{45}+\beta_{7} \dot{\mathrm{P}}^{\mathrm{e}}+\beta_{8} \mathrm{ER}+\beta_{9}$ Trend $+\mu$

where PS stands for personal savings, Y for GNP, CD for cyclical deficit, SD for structural deficit, YD for real disposable income, $\dot{\mathrm{P}}^{\mathrm{e}}$ for the expected inflation rate, ER for the real ex-ante exchange rate, and $\mathrm{A}_{25}, \mathrm{~A}_{35}, \mathrm{~A}_{45}$ are the percentages of population in the age range of $25-34,35-44$ and $45-54$, respectively. The authors use seasonally adjusted quarterly data. The equation is estimated for the period 1973:2 to 1991:4 using the instrumental variables technique. ${ }^{18}$

Their results give a partial support to Ricardian equivalence; they suggest a partial crowding out. The savings rate is found to respond positively to the structural deficit, which is supportive of Ricardian equivalence, but is not responsive to the cyclical deficit, which is against equivalence. Thus, the results suggest that the Ricardian equivalence is incomplete in the U. S. A.

\footnotetext{
17 As mentioned before, the Ricardian equivalence argumentation is only valid for a constant level government spending.

${ }_{18}$ The instruments are the two quarters lag of the seasonally adjusted unemployment rate, and the two quarters lag of the actual inflation rate. According to the authors these instruments explain the cyclical deficit and expected inflation without being correlated with the contemporaneous error term.
} 
Differently from the conventional narrative review of Ricardian equivalence, Stanley (1998) has conducted a quantitative review, or meta-analysis, of 28 empirical studies on that subject. He concluded against the validity of Ricardian equivalence. Moreover, his results suggest that the likelihood of Ricardian equivalence empirical rejection increases with the number of specification tests and with larger degrees of freedom, which is consistent only with the falsity of the null hypothesis of Ricardian equivalence.

According to Stanley (1998) the standard consumption function used to test the equivalence is:

$\mathrm{C}_{\mathrm{t}}=\alpha_{0}+\alpha_{1} \mathrm{Y}_{\mathrm{t}}+\alpha_{2} \mathrm{Y}_{\mathrm{t}-1}+\alpha_{3} \mathrm{G}_{\mathrm{t}}+\alpha_{4} \mathrm{~W}_{\mathrm{t}}+\alpha_{5} \mathrm{TX}_{\mathrm{t}}+\alpha_{6} \mathrm{~GB}_{\mathrm{t}}+\alpha_{7} \mathrm{TR}_{\mathrm{t}}+\varepsilon_{\mathrm{t}}$

The Ricardian equivalence implies $\alpha_{5}=\alpha_{6}=\alpha_{7}=0$.

In the context of the literature on fiscal federalism, Bayoumi and Masson (1998) distinguish liability-creating from non-liability creating deficits. According to the authors, the level of government at which fiscal policy is used has an effect on its net impact on the economy. To see such an outcome lets consider the use of fiscal policy with stabilising purposes, within a federal state. When a local government provides stabilisation, to its own local economy, it has a direct impact on that local government debt. Consequently, it is likely that the local citizens take into account the future tax obligations implicit in the local debt. On the other hand, when a federal government provides stabilisation across a number of regions facing idiosyncratic shocks, the impact on federal debt will tend to cancel out, implying no expectation of future tax liabilities. Therefore, if Ricardian equivalence is complete, local governments are unable to provide local stabilisation, while the federal government is able to provide stabilisation across the several regions. ${ }^{19}$

\subsubsection{Euler equation approach}

The Euler equation approach has the advantage of being explicitly based on the intertemporal optimisation problem (it has micro-foundations). It also enables to test directly two sources of deviation from Ricardian equivalence: the finiteness of the planning horizon and the excess sensitivity of consumption to current income. Despite its advantages this method has several drawbacks too. Namely, it is necessary to impose several restrictive assumptions in order to derive an aggregate consumption function in terms of observable variables from the original optimisation problem.

A good example of those restrictive assumptions is the imposition of a constant real rate of return, $r$, which is equal for both the individuals and the government. It is also necessary to assume a specific form for the utility function, e.g. a quadratic form, in order to aggregate the Euler equation across individuals. It is common to assume lumpsum taxes, which limits the possibilities of rejecting the equivalence. The Euler approach also focuses on disposable income, abstracting from the impact of transfer payments.

${ }^{19}$ The stabilisation is being provided across regions rather than across time. 
In this section we will follow closely the work of Brunila (1997), which is an extension of the work of Hayashi (1982), Blanchard (1985), and Evans (1988, 1993). The author tested Ricardian equivalence for a group of ten European countries ${ }^{20}$ chosen according to data availability.

\subsubsection{A generalised permanent income model}

In order to derive the aggregated consumption function, Blanchard's (1985) solution is used. It is assumed that all consumers face the same probability of death, p, at each point in time. This parameter measures the finiteness of life and can be interpreted in several ways: as an horizon index between zero and infinity, as the disconnection of current consumers from future generations, or as the myopia with which consumers foresee future taxes (Brunila, 1997: 26).

To derive a closed-form solution for private consumption it is necessary to assume that consumers have an unrestricted access to capital markets. They could accumulate or deccumulate assets at the same constant real rate of return as the government. It is also assumed that there are riskless insurance (annuity) markets ${ }^{21}$ in which insurance (annuity) companies in each period make (receive) an annuity payment to (from) each consumer with positive (negative) financial wealth and inherit all the consumer's financial wealth at his death. The model consequently excludes the bequest motive.

Each consumer born in period $\mathrm{t}-\mathrm{k}$ and still alive in period $\mathrm{t}$ is assumed to maximise his expected lifetime utility as of period $\mathrm{t}$ :

$\operatorname{Max} E_{t} \sum_{j=0}^{\infty}(\gamma \beta)^{i} U\left(c_{t+j, k+j}^{T}\right), \quad 0<\gamma \leq 1$

With $c_{t, k}^{\mathrm{T}}=c_{t, k}^{\mathrm{P}}+\theta g_{\mathrm{t}}, \theta_{<}^{>} 0$

Subject to the sequence of one-period flow budget constraints:

$$
\begin{aligned}
\mathrm{c}_{\mathrm{t}, \mathrm{k}}^{\mathrm{T}} & =\mathrm{y}_{\mathrm{t}, \mathrm{k}}+\tau_{\mathrm{t}, \mathrm{k}}-\mathrm{a}_{\mathrm{t}, \mathrm{k}}+\frac{1+\mathrm{r}}{\gamma} \mathrm{a}_{\mathrm{t}-1, \mathrm{k}-\mathrm{l}}+\theta \mathrm{g}_{\mathrm{t}} \\
& =\mathrm{h}_{\mathrm{t}, \mathrm{k}}-\mathrm{a}_{\mathrm{t}, \mathrm{k}}+\frac{1+\mathrm{r}}{\gamma} \mathrm{a}_{\mathrm{t}-1, \mathrm{k}-\mathrm{l}}+\theta \mathrm{g}_{\mathrm{t}}
\end{aligned}
$$

Where $c_{t, k}^{T}$ stands for total effective real consumption of a consumer of age $k$ at period $\mathrm{t}, \beta$ is the subjective discount factor $(1+\delta)^{-1}$ being $\delta$ the constant positive rate of subjective time preference, $\gamma=1-p,{ }^{22} u\left(c_{t}^{T}\right)$ is a time-invariant, one period utility function satisfying $u^{\prime}>0$ and $u$ ' $<0$. The total consumption is a linear combination of private consumption, $\mathrm{c}_{\mathrm{t}}^{\mathrm{P}}$, and government consumption $\mathrm{g}_{\mathrm{t}} \mathrm{y}$ is real before-tax labour income, $\tau$ is real government transfers, $t$ is real gross lump-sum tax payments, $h=y+\tau-t$ is real disposable labour income (human health), a is real non labour assets (or debt, if negative) including government bonds, and $r$ is the constant real interest rate. $E_{t}$ is the

\footnotetext{
${ }^{20}$ Austria, Belgium, Finland, France, Germany, Greece, Italy, the Netherlands, Sweden, and the U.K.

${ }^{21}$ The insurance and annuity markets are assumed to be actuarially fair, i.e. the zero profit conditions applies.

${ }^{22}$ Being $\gamma=1-\mathrm{p}$, the expected life of each individual is $1 /(1-\gamma)$. The risk adjusted interest factor is $(1+\mathrm{r}) / \gamma$.

G.E.M.F. - F.E.U.C. 
mathematical expectation operator conditional on information known to the consumer in period $\mathrm{t}$.

From the first-order conditions follows the set of Euler equations:

$$
E_{t} u^{\prime}\left(c_{t+j, k+j}^{T}\right)=[\beta(1+r)]^{-j} u^{\prime}\left(c_{t, k}^{T}\right)
$$

In order to aggregate the Euler equations across individuals it is necessary to assume a specific form for the utility function. Brunila (1997) assumes exogenous uncertainty and a quadratic one-period utility function ${ }^{23}$ of the form:

$$
\mathrm{u}\left(\mathrm{c}_{\mathrm{t}}^{\mathrm{T}}\right)=-\frac{1}{2}\left(\overline{\mathrm{c}}-\mathrm{c}_{\mathrm{t}}^{\mathrm{T}}\right)^{2}
$$

where $\bar{c}$ is the bliss level of consumption. This assumption enables the Euler equation to be rewritten as:

$$
\mathrm{E}_{\mathrm{t}} \mathrm{c}_{\mathrm{t}+1}^{\mathrm{T}}=\frac{\mathrm{r}-\delta}{1+\mathrm{r}} \overline{\mathrm{c}}+\frac{\mathrm{r}-\delta}{1+\mathrm{r}} \mathrm{c}_{\mathrm{t}}^{\mathrm{T}}
$$

With the necessary transformations (see Brunila, 1997 for details) one obtains the aggregated per capita private consumption, $c_{t}^{p}$, as a function of expected aggregate per capita wealth:

$c_{t}^{p}=\beta_{0}+\beta_{1}\left(E_{t} H_{t}+\theta E_{t} G_{t}+(1+r) a_{t-1}\right)-\theta g_{t}$

where the capital letters represent the present value of the discounted stream of the future values of each variable, e.g. $\mathrm{H}_{\mathrm{t}}$ is the present value of the human health.

In order to empirically estimate the equation above it is solved in terms of $c_{t-1}^{\mathrm{P}}$. Nonlabour assets are also eliminated from the equation, ${ }^{24}$ given rise to:

$$
\begin{aligned}
c_{t}^{P}= & -r \beta_{0}+(1+r)\left(1-\beta_{1}\right) c_{t-1}^{P}+\beta_{1}(1-\gamma) E_{t} H_{t}+\beta_{1} \theta(1-\gamma) E_{t} G_{t}-\theta g_{t} \\
& +(1+r)\left(1-\beta_{1}\right) \theta g_{t-1}+\beta_{1} \gamma\left(e_{H t}+\theta e_{G t}\right)+u_{t}
\end{aligned}
$$

with error terms that reflect the revisions in expectations about $h_{t+j}$ and $g_{t+j}$ :

$$
e_{H t}=\left(E_{t}-E_{t-1}\right) \sum_{j=0}^{\infty}\left(\frac{\gamma}{1+r}\right)^{j} h_{t+j}
$$

and

$$
e_{G t}=\left(E_{t}-E_{t-1}\right) \sum_{j=0}^{\infty}\left(\frac{\gamma}{1+r}\right)^{j} g_{t+j}
$$

\footnotetext{
${ }^{23}$ The use of a quadratic utility function has some disadvantages. It implies an increasing absolute risk aversion, which rules out the precautionary savings motive due to uncertainty. Moreover, the marginal utility is linear in consumption (i.e., u" " $=0$ ), implying that an increase in the variance of consumption has no effect on its expected marginal utility, and consequently no effect on the optimal behaviour.

${ }^{24}$ The reason for that elimination was the absence of internationally compatible and reliable data. See Brunilla (1997: appendix 1) for details.
} 
The unexpected changes in private consumption from one period to the following are due to changes in expected lifetime wealth (i.e., permanent income) resulting from unexpected changes in labour income, net taxes and government consumption.

This equation nests both Ricardian equivalence and the non-Ricardian view as special cases. The key parameters in assessing Ricardian equivalence are $\gamma$ and $\theta$. When $\gamma=1$ the consumers have an infinite horizon. As they are forward-looking rational agents Ricardian equivalence holds, and deficits have no effect on current consumption.

When $\gamma$ is less than unity $(0<\gamma<1)$ consumers have a shorter planning horizon than the government. Therefore, government bonds are regarded as net wealth. This positive wealth effect is due to different discount rates: consumers discount future taxes at a rate $\gamma /(1+r)$ smaller than the rate at which the future interest income on government bonds is discounted, which is $1 /(1+\mathrm{r})$. The weight that is attributed to the increase in future taxes is smaller than the one attributed to the current tax cut. One unit of additional taxes in period $t+j$ has the present value of $[\gamma /(1+r)]^{j}$, which is smaller than $(1+r)^{-j}$, the present value of one unit of interest income on bonds (Brunila, 1997: 39). In the case of extreme myopia $(\gamma=0)$, consumers treat government bonds fully as net wealth.

The sign of $\theta$ has implications for the relation between government consumption and private consumption. $\theta>0$ implies that an increase in government consumption diminishes the marginal utility of private consumption (i.e., the two are substitutes) ${ }^{25}$ leading to a decline in the latter, i.e. a direct crowding out. ${ }^{26}$ If $\theta<0$ an increase in government consumption increases the marginal utility of private consumption (i.e., the two are complements).

In order to derive the reduced-form consumption function it is necessary to get rid of the expectation operators. The author postulated stochastic difference equations implied by the rational expectations assumption, using Hayashi's (1982) procedure. The changes in the expected values of disposable labour income and government consumption from period $\mathrm{t}-1$ to period $\mathrm{t}$ are assumed to be determined by the present value of period t-1 disposable labour income and government consumption and unexpected changes in these variables $\left(\mathrm{e}_{\mathrm{Ht}}\right.$ and $\left.\mathrm{e}_{\mathrm{Gt}}\right)$ :

$$
\begin{aligned}
& \mathrm{E}_{\mathrm{t}} \mathrm{H}_{\mathrm{t}}-\frac{1+\mathrm{r}}{\gamma} \mathrm{E}_{\mathrm{t}-1} \mathrm{H}_{\mathrm{t}-1}=-\frac{1+\mathrm{r}}{\gamma} \mathrm{h}_{\mathrm{t}-1}+\mathrm{e}_{\mathrm{Ht}} \\
& \mathrm{E}_{\mathrm{t}} \mathrm{G}_{\mathrm{t}}-\frac{1+\mathrm{r}}{\gamma} \mathrm{E}_{\mathrm{t}-1} \mathrm{G}_{\mathrm{t}-1}=-\frac{1+\mathrm{r}}{\gamma} \mathrm{g}_{\mathrm{t}-1}+\mathrm{e}_{\mathrm{Gt}}
\end{aligned}
$$

The per capita consumption function in terms of observable variables thus becomes:

$$
\begin{aligned}
c_{t}^{\mathrm{p}}= & \beta_{0}^{\prime}+\left[(1+\mathrm{r})\left(1-\beta_{1}\right)+\frac{1+\mathrm{r}}{\gamma}\right] \mathrm{c}_{\mathrm{t}-1}^{\mathrm{P}}-\left(1-\beta_{1}\right) \frac{(1+\mathrm{r})^{2}}{\gamma} \mathrm{c}_{\mathrm{t}-2}^{\mathrm{P}}-\beta_{1}(1-\gamma) \frac{1+\mathrm{r}}{\gamma} \mathrm{h}_{\mathrm{t}-1}-\theta \mathrm{g}_{\mathrm{t}} \\
& +\theta\left(1-\beta_{1}+\gamma\right) \frac{1+\mathrm{r}}{\gamma} \mathrm{g}_{\mathrm{t}-1}-\theta\left(1-\beta_{1}\right) \frac{(1+\mathrm{r})^{2}}{\gamma} \mathrm{g}_{\mathrm{t}-2}+\mathrm{v}_{\mathrm{t}}
\end{aligned}
$$

where,

\footnotetext{
${ }^{25}$ In the sense of Auspitz-Lieben-Edgworth-Pareto and not in the sense of Hicks-Allen.

${ }^{26}$ Although there is a direct crowding out, as long as $0<\theta<1$ aggregate demand will increase by a fraction of $(1-\theta)$ of the increase in government spending.
} 


$$
\beta_{0}^{\prime}=\frac{\mathrm{r}(\delta-\mathrm{r})}{1+\mathrm{r}} \overline{\mathrm{c}}, \quad \beta_{1}=1-\frac{\gamma(1+\delta)}{(1+\mathrm{r})^{2}}
$$

and

$$
\mathrm{v}_{\mathrm{t}}=\beta_{1}\left(\mathrm{e}_{\mathrm{Ht}}+\theta \mathrm{e}_{\mathrm{Gt}}\right)-\beta_{1}(1+\mathrm{r})\left(\mathrm{e}_{\mathrm{Ht}-1}+\theta \mathrm{e}_{\mathrm{Gt}-1}\right)+\mathrm{u}_{\mathrm{t}}-\frac{1+\mathrm{r}}{\gamma} \mathrm{u}_{\mathrm{t}-1} .
$$

This method used to derive the reduced form consumption function has the disadvantage of reaching a backward looking equation that is supposed to reflect forward-looking expectations, i.e. it assumes that in the formulation of the future expectations only past and current information is taken into account.

The author used the Generalised Method of Moments (GMM) estimator with twicelagged variables as instruments, because the error term of the consumption equation has a first-order moving average structure, MA(1). ${ }^{27}$ This method gives rise to heteroscedasticy-and-autocorrelation-consistent standard errors.

The equation is estimated in levels because Brunila (1997) concluded that the variables might be considered to be co-integrated. The estimations are performed assuming $\mathrm{r}=\delta=3 \%$, as it is common practice in these kind of studies. This implies a drop of the constant term $\beta_{0}^{\prime}$ and $\beta_{1}=(1+r-\gamma) /(1+r)$.

In six out of ten countries $\gamma=1$, which means that an infinite planning horizon could not be rejected. These results give support to the Ricardian equivalence hypothesis. However, the estimated coefficients for $\beta_{1}$, the propensity to consume out of total expected wealth, were found to be excessively high, given an infinite planning horizon for consumers. This high value could be the result of measurement errors in consumption or disposable labour income and, more importantly in Brunila's (1997) judgement, to liquidity constraints. Those induce excess sensitivity of consumption to current income. ${ }^{28}$

\subsubsection{Excess sensitivity and permanent income hypothesis}

When capital market imperfections prevent consumers from borrowing to smooth consumption over transitory fluctuations in income, consumption becomes constrained by current income. Private consumption becomes too sensitive to current income violating the permanent income model predictions. In this case, government deficits will have real effects, even if consumers optimise over an infinite horizon $(\gamma=1)$.

The permanent income consumption model could be extended to include a fraction $\lambda$ of income that goes to rule-of-thumb (Keynesian) consumers. Those consumers are assumed to have no assets and no access to capital markets. They follow a simple Keynesian consumption function without borrowing and without non-labour assets. The best they can do is to consume all their disposable income. Therefore, the rule-ofthumb consumption, $\mathrm{c}_{\mathrm{t}}^{\mathrm{K}}$ will be equal to their share of total labour income:

\footnotetext{
${ }^{27}$ The MA(1) structure is due to measurement errors of consumption and to possible non orthogonality between $\mathrm{e}_{\mathrm{Ht}}$ and $\mathrm{e}_{\mathrm{Gt}}$ to $\mathrm{h}_{\mathrm{t}}$ and $\mathrm{g}_{\mathrm{t}}$.

${ }^{28}$ The high value of $\beta_{1}$ could also be due to the mathematical solution used to eliminate non-labour wealth from the estimation equation.
} 
$c_{t}^{K}=\lambda h_{t}$

Aggregating over rule-of-thumb and permanent-income consumers the extended aggregate per capita consumption function becomes:

$c_{t}^{p}=\beta_{0}+\lambda h_{t}+\beta_{1}\left[(1-\lambda) E_{t} H_{t}+\theta(1-\lambda) E_{t} G_{t}+(1+r) a_{t-1}\right]-\theta(1-\lambda) g_{t}$

In terms of observable variables (and eliminating non-labour assets):

$$
\begin{aligned}
c_{t}^{\mathrm{P}}= & \beta_{0}^{\prime}+\left[(1+\mathrm{r})\left(1-\beta_{1}\right)+\frac{1+\mathrm{r}}{\gamma}\right] \mathrm{c}_{\mathrm{t}-1}^{\mathrm{P}}-\left(1-\beta_{1}\right) \frac{(1+\mathrm{r})^{2}}{\gamma} \mathrm{c}_{\mathrm{t}-2}^{\mathrm{P}}+\lambda \mathrm{h}_{\mathrm{t}}-\frac{1+\mathrm{r}}{\gamma}\left(\lambda(1+\gamma)+\beta_{1}(1-\lambda-\gamma)\right) \mathrm{h}_{\mathrm{t}-1} \\
& +\lambda \frac{(1+\mathrm{r})^{2}}{\gamma}\left(1-\beta_{1}\right) \mathrm{h}_{\mathrm{t}-2}-\theta(1-\lambda) \mathrm{g}_{\mathrm{t}}+\theta\left(1+\gamma-\beta_{1}\right)(1-\lambda) \frac{1+\mathrm{r}}{\gamma} \mathrm{g}_{\mathrm{t}-1}-\theta\left(1-\beta_{1}\right)(1-\lambda) \frac{(1+\mathrm{r})^{2}}{\gamma} \mathrm{g}_{\mathrm{t}-2}+\mathrm{z}_{\mathrm{t}}
\end{aligned}
$$

where

$\mathrm{z}_{\mathrm{t}}=\beta_{1}(1-\lambda)\left(\mathrm{e}_{\mathrm{Ht}}+\theta \mathrm{e}_{\mathrm{Gt}}\right)-\beta_{1}(1-\lambda)(1+\mathrm{r})\left(\mathrm{e}_{\mathrm{Ht}-1}+\theta \mathrm{e}_{\mathrm{Gt}-1}\right)+(1-\lambda) \mathrm{u}_{\mathrm{t}}-(1-\lambda) \frac{1+\mathrm{r}}{\gamma} \mathrm{u}_{\mathrm{t}-1}$

For Ricardian equivalence to hold the planning horizon of forward-looking consumers should be infinite, i.e. $\gamma=1$, and the fraction of rule-of-thumb consumers should be zero, $\lambda=0$.

The empirical results of Brunila (1997) show that deviations from Ricardian equivalence are more due to excess sensitivity of consumption to current income ${ }^{29}$ rather than to a shorter planning horizon for consumers. ${ }^{30}$

Brunila (1997) tested also an extended model with a $\lambda$ that was allowed to change over time. However, the results were not significantly different from those obtained with a constant- $\lambda$ model.

\subsubsection{A permanent income hypothesis with a consolidated government sector}

It is also possible to rational consumers to incorporate the government solvency condition in their optimisation problem. The solvency condition is:

$$
t_{t}=g_{t}+\tau_{t}-b_{t}+(1+r) g b_{t-1}
$$

where gb denotes the real per capita government debt, $t$ are tax revenues, and $\tau$ are government transfer payments.

The consolidated model for consumption than becomes:

$$
\begin{aligned}
c_{t}^{\mathrm{P}}= & -r \beta_{0}+(1+r)\left(1-\beta_{1}\right) c_{t-1}+\beta_{1}(1-\gamma) \mathrm{E}_{\mathrm{t}} \mathrm{Y}_{\mathrm{t}}+\beta_{1}(1-\gamma)(\theta-1) \mathrm{E}_{\mathrm{t}} \mathrm{G}_{\mathrm{t}}-\theta \mathrm{g}_{\mathrm{t}} \\
& +(1+\mathrm{r})\left(1-\beta_{1}\right) \theta \mathrm{g}_{\mathrm{t}-1}-\beta_{1}(1+\mathrm{r})(1-\gamma) \mathrm{g} \mathrm{b}_{\mathrm{t}-1}+\beta_{1} \varepsilon_{\mathrm{t}}+\mathrm{u}_{\mathrm{t}}
\end{aligned}
$$

\footnotetext{
${ }^{29}$ In France, Germany, Greece, Italy and UK.

${ }^{30}$ As it was the case for Finland, Netherlands and Sweden.
} 
Where $\mathrm{Y}$ is the expected present value of the discounted stream of the future pre-tax labour income.

The revisions in expectations arising from unexpected changes in labour income and government expenditure are captured by the error term $\varepsilon_{\mathrm{t}}=\left(\gamma \mathrm{e}_{\mathrm{Yt}}+\gamma \theta \mathrm{e}_{\mathrm{Gt}}\right)$.

This equation is more restrictive in terms of innovation process than the previous ones. The consumption responds only to unexpected changes in labour income and government consumption. It does not respond, as before, to unexpected changes in net taxes. It is a more Ricardian equation.

The reduced form in terms of observable variables is:

$$
\begin{aligned}
c_{t}^{\mathrm{P}} & =\beta_{0}^{\prime}+\left[(1+\mathrm{r})\left(1-\beta_{1}\right)+\frac{1+\mathrm{r}}{\gamma}\right] \mathrm{c}_{\mathrm{t}-1}^{\mathrm{P}}-\left(1-\beta_{1}\right) \frac{(1+\mathrm{r})^{2}}{\gamma} \mathrm{c}_{\mathrm{t}-2}^{\mathrm{P}}-\beta_{1}(1-\gamma) \frac{1+\mathrm{r}}{\gamma} \mathrm{y}_{\mathrm{t}-1}-\theta \mathrm{g}_{\mathrm{t}} \\
& +\theta\left[1-\beta_{1}\left(\frac{\gamma-1}{\theta}+1\right)+\gamma\right] \frac{1+\mathrm{r}}{\gamma} \mathrm{g}_{\mathrm{t}-1}-\theta\left(1-\beta_{1}\right) \frac{(1+\mathrm{r})^{2}}{\gamma} \mathrm{g}_{\mathrm{t}-2}-\beta_{1}(1-\gamma)(1+\mathrm{r}) \mathrm{gb} \mathrm{t}_{\mathrm{t}-1} \\
& +\beta_{1}(1-\gamma) \frac{(1+\mathrm{r})^{2}}{\gamma} \mathrm{gb}_{\mathrm{t}-2}+\mathrm{z}_{\mathrm{t}}
\end{aligned}
$$

The error term has a MA(1) structure:

$$
\mathrm{v}_{\mathrm{t}}=\beta_{1}\left(\mathrm{e}_{\mathrm{Yt}}+\theta \mathrm{e}_{\mathrm{Gt}}\right)-\beta_{1}(1+\mathrm{r})\left(\mathrm{e}_{\mathrm{Yt}-1}+\theta \mathrm{e}_{\mathrm{Gt}-1}\right)+\mathrm{u}_{\mathrm{t}}-\frac{1+\mathrm{r}}{\gamma} \mathrm{u}_{\mathrm{t}-1}
$$

The Ricardian equivalence holds when $\gamma=1$.

Taking into account the excess sensitivity hypothesis, with a constant- $\lambda$, the consumption function becomes:

$$
\begin{aligned}
c_{t}^{\mathrm{P}}= & -r \beta_{0}+(1+r)\left(1-\beta_{1}\right) c_{t-1}+\beta_{1}(1-\gamma)(1-\lambda) \mathrm{E}_{\mathrm{t}} \mathrm{Y}_{\mathrm{t}}+\beta_{1}(1-\gamma)(\theta-1)(1-\lambda) \mathrm{E}_{\mathrm{t}} \mathrm{G}_{\mathrm{t}}+\lambda \mathrm{h}_{\mathrm{t}} \\
& -\lambda(1+\mathrm{r})\left(1-\beta_{1}\right) \mathrm{h}_{\mathrm{t}-1}-\theta(1-\lambda) \mathrm{g}_{\mathrm{t}} \\
& +(1+\mathrm{r})\left(1-\beta_{1}\right) \theta(1-\lambda) \mathrm{g}_{\mathrm{t}-1}-\beta_{1}(1+\mathrm{r})(1-\gamma)(1-\lambda) g \mathrm{~b}_{\mathrm{t}-1}+\beta_{1}(1-\lambda) \varepsilon_{\mathrm{t}}+\mathrm{u}_{\mathrm{t}}
\end{aligned}
$$

In terms of observable variables one obtains: 


$$
\begin{aligned}
\mathrm{c}_{\mathrm{t}}^{\mathrm{P}}= & \beta_{0}^{\prime}+\left[(1+\mathrm{r})\left(1-\beta_{1}\right)+\frac{1+\mathrm{r}}{\gamma}\right] \mathrm{c}_{\mathrm{t}-1}^{\mathrm{P}}-\left(1-\beta_{1}\right) \frac{(1+\mathrm{r})^{2}}{\gamma} \mathrm{c}_{\mathrm{t}-2}^{\mathrm{P}}+\lambda \mathrm{h}_{\mathrm{t}}-\lambda\left[(1+\mathrm{r})\left(1-\beta_{1}\right)+\frac{1+\mathrm{r}}{\gamma}\right] \mathrm{h}_{\mathrm{t}-1} \\
& +\lambda \frac{(1+\mathrm{r})^{2}}{\gamma}\left(1-\beta_{1}\right) \mathrm{h}_{\mathrm{t}-2}-\beta_{1}(1-\gamma)(1-\lambda) \frac{1+\mathrm{r}}{\gamma} \mathrm{y}_{\mathrm{t}-1}-\theta(1-\lambda) \mathrm{g}_{\mathrm{t}} \\
& +\theta\left[1+\gamma-\frac{\beta_{1}(\theta+\gamma-1)}{\theta}\right] \frac{1+\mathrm{r}}{\gamma} \mathrm{g}_{\mathrm{t}-1}-\theta \frac{(1+\mathrm{r})^{2}}{\gamma}\left(1-\beta_{1}\right)(1-\lambda) \mathrm{g}_{\mathrm{t}-2} \\
& -\beta_{1}(1+\mathrm{r})(1-\gamma)(1-\lambda)\left(\mathrm{gb}_{\mathrm{t}-1}-\frac{1+\mathrm{r}}{\gamma} \mathrm{gb}_{\mathrm{t}-2}\right)+\mathrm{v}_{\mathrm{t}}
\end{aligned}
$$

with the error term

$$
\mathrm{v}_{\mathrm{t}}=\beta_{1}(1-\lambda)\left(\mathrm{e}_{\mathrm{Yt}}+\theta \mathrm{e}_{\mathrm{Gt}}\right)-\beta_{1}(1-\lambda)(1+\mathrm{r})\left(\mathrm{e}_{\mathrm{Yt}-1}+\theta \mathrm{e}_{\mathrm{Gt}-1}\right)+(1-\lambda) \mathrm{u}_{\mathrm{t}}-(1-\lambda) \frac{1+\mathrm{r}}{\gamma} \mathrm{u}_{\mathrm{t}-1}
$$

The empirical estimates of Brunila (1997) show that the infinite horizon hypothesis can not be rejected for all studied countries. However, the restriction $\gamma=1$ and $\lambda=0$, which is required for Ricardian equivalence, is rejected for all countries except Finland, the Netherlands and Sweden at the 5\% significance level. Brunila (1997: 112) argues as well that the results for those three countries in favour of the equivalence should be interpreted with caution because the estimated value of the propensity to consume out of total expected wealth $\left(\beta_{1}\right)$ is too high to conform to an infinite planning horizon. ${ }^{31}$ Therefore, Brunila (1997) concludes for the non-validity of Ricardian equivalence in her sample of European countries. It appears to be a scope for fiscal deficits to have real effects, and to be potentially useful in aggregate demand management.

\section{Empirical application to the Portuguese economy}

Taking as a point of departure the previous models, an empirical application to the Portuguese economy is conducted. Firstly, the time series properties of the data are studied. Secondly, structural consumption functions are estimated. The last part is the use of the Euler consumption function approach.

\subsection{Time Series Properties of the Data}

In order to check the order of integration of the series the Augmented Dickey Fuller (ADF) test is used.

\subsubsection{The ADF test}

\subsubsection{Theoretical background}

Suppose that $\mathrm{X}_{\mathrm{t}}$ is generated by the process:

$\mathrm{X}_{\mathrm{t}}=\delta+\phi_{1} \mathrm{X}_{\mathrm{t}-1}+\varepsilon_{\mathrm{t}}$, where $\varepsilon_{\mathrm{t}}$ is a white noise. If $\mathrm{X}_{\mathrm{t}}$ is a stationary process it has a constant average $\mathrm{E}\left[\mathrm{X}_{\mathrm{t}}\right]=\mathrm{E}\left[\mathrm{X}_{\mathrm{t}-1}\right]=\mu$, therefore

\footnotetext{
${ }^{31}$ The estimates of the substitutability parameter were in general insignificant.
} 


$$
\mu=\delta+\phi_{1} \mu \text { and } \mu=\frac{\delta}{1-\phi_{1}}
$$

In order to have a finite average, one should have $\phi_{1} \neq 1$. With $\phi_{1}=1+\alpha$ we obtain:

$$
\Delta \mathrm{X}_{\mathrm{t}}=\delta+\alpha \mathrm{X}_{\mathrm{t}-1}+\varepsilon_{\mathrm{t}}
$$

When $\alpha=0$ the variable is a random walk, and therefore is not stationary. Stationarity implies a negative value for $\alpha$. In order the test to be valid the error term should be white noise. In order to fulfil this requirement one adds lagged difference of the series until the residuals of the regression are white noise. This is the Augmented DickeyFuller test. The null of non-stationary is tested by $\alpha=0$. In the following equation:

$$
\Delta \mathrm{X}_{\mathrm{t}}=\delta+\alpha \mathrm{X}_{\mathrm{t}-1}+\sum_{\mathrm{j}=1}^{\mathrm{k}} \Delta \mathrm{X}_{\mathrm{t}-\mathrm{j}}+\varepsilon_{\mathrm{t}}
$$

A time trend could also be included. The appropriate number of lagged differences by adding lags until a Lagrange Multiplier test fails to reject no serial correlation at conventional significance level. The used ADF test is a t-test to the coefficient $\alpha$. There is also the so-called z-test, which is given by $T . \alpha$, where $\mathrm{T}$ is the number of observations. The critical values for both tests are non-conventional.

\subsubsection{Results of the ADF test}

Table 1 - Key to variable abbreviations, and deflators used

\begin{tabular}{lll}
\hline Abrev. & Variable & Deflator \\
\hline C & Private consumption & Published \\
\hline GDP & GDP & Published \\
\hline YD & Disposable income & GDP \\
\hline Y & $\begin{array}{l}\text { Disposable non-property } \\
\text { income (labour income) }\end{array}$ & GDP \\
\hline TX & $\begin{array}{l}\text { Pre-tax disposable non- } \\
\text { property income }\end{array}$ & GDP \\
\hline GDP-TX & $\begin{array}{l}\text { Taxes (income taxes and } \\
\text { social security) }\end{array}$ & Private consumption \\
& $\begin{array}{l}\text { Net income measure used } \\
\text { Per testing Pereleman and }\end{array}$ & See each variable \\
\hline G & Public consumption & Published \\
\hline TRANSFERS & Transfers & Private consumption \\
\hline GINT & Interest on public debt & Private consumption \\
\hline GB & $\begin{array}{l}\text { Total Public Debt, book } \\
\text { value }\end{array}$ & GDP \\
\hline DEF & Budget Deficit & Private consumption \\
\hline K1, K2 & Proxy Capital Stock & - \\
\hline W1, W2 & Proxy Wealth & - \\
\hline Note: See the appendix for a description of the construction of the variables K1 and K2.
\end{tabular}


Table 2- Augmented Dickey-Fuller Test (ADF)

\begin{tabular}{lcccccc|c}
\hline Variable & \multicolumn{1}{c}{ Levels } & \multicolumn{5}{c|}{ First Differences } & Concl. \\
\hline C & Lag & ADF & LM & Lag & ADF & LM & \\
\hline GDP & 1 & 0.9535 & 0.877 & 0 & -3.7893 & 0.785 & $\mathrm{I}(1)$ \\
\hline YD & 1 & 0.7796 & 0.298 & 0 & -3.4901 & 0.414 & $\mathrm{I}(1)$ \\
\hline LINC $(\mathrm{h})$ & 1 & 0.0472 & 0.795 & 0 & -4.2141 & 0.800 & $\mathrm{I}(1)$ \\
\hline Y & 1 & -0.1896 & 0.121 & 0 & -3.5403 & 0.117 & $\mathrm{I}(1)$ \\
\hline G & 1 & -0.1678 & 0.362 & 0 & -3.4131 & 0.349 & $\mathrm{I}(1)$ \\
\hline TX & 0 & 2.5957 & 0.071 & 0 & -4.2991 & 0.260 & $\mathrm{I}(1)$ \\
\hline GDP-TX & 0 & 3.2468 & 0.564 & 0 & -4.5638 & 0.755 & $\mathrm{I}(1)$ \\
\hline TRANSFERS & 1 & 0.2429 & 0.135 & 0 & -3.8727 & 0.237 & $\mathrm{I}(1)$ \\
\hline GINT & 2 & 3.0161 & 0.934 & 0 & -3.1992 & 0.235 & $\mathrm{I}(1)$ \\
\hline GB & 0 & -0.6162 & 0.134 & 0 & -5.0089 & 0.240 & $\mathrm{I}(1)$ \\
\hline DEF & 0 & 1.3904 & 0.879 & 0 & -5.8975 & 0.260 & $\mathrm{I}(1)$ \\
\hline K1 & 0 & -1.6764 & 0.756 & 1 & -6.4513 & 0.545 & $\mathrm{I}(1)$ \\
\hline K2 & 2 & 2.9434 & 0.856 & 0 & -0.9745 & 0.190 & $\mathrm{I}(2) ?$ \\
\hline W1 & 2 & 2.8736 & 0.804 & 0 & -1.2713 & 0.152 & $\mathrm{I}(2) ?$ \\
\hline W2 & 2 & 2.4478 & 0.777 & 0 & -1.9553 & 0.177 & $\mathrm{I}(2) ?$ \\
\hline W1 with trend & 2 & 2.2899 & 0.821 & 0 & -2.1869 & 0.138 & $\mathrm{I}(2) ?$ \\
\hline W2 with trend & & & 1 & -3.5132 & 0.681 & $\mathrm{I}(1)$ at $10 \%$ \\
\hline K1 with trend & & & & 1 & -3.6472 & 0.75 & $\mathrm{I}(1)$ \\
\hline K2 with trend & & & & 1 & -3.0231 & 0.903 & $\mathrm{I}(2) ?$ \\
\hline
\end{tabular}

Notes: The first block of variables are in per capita real terms. The Mackinnon (1991) critical values at the 5\% significance level are: -2.9358 for processes with a constant and no trend for the variables in levels; -2.9320 for the first differences. At the $10 \%$ significance level the critical value is -2.6039 . For the process with constant and trend the critical values are: -3.51 at the 5\% significance level; and -3.19 at the $10 \%$ significance level.

LM denotes the p-value of the chi-squared of the Lagrange Multiplier test under the null of no firstorder autocorrelation. The value of the lag to include in the ADF test was chosen by adding lags until the Lagrange Multiplier test failed to reject no serial correlation at the 5\% significance level.

The ADF test without trend results indicate that the null hypothesis that the series in levels has one unit root cannot be rejected at the 5\% significance level. The null hypothesis that each first-differenced series has one unit root can be rejected for all series at the 5\% significance level, except for the capital stock and wealth variables. However, the null of the presence of one unit root the first difference of series $\mathrm{K} 2$ and W2 can be rejected (at the $10 \%$ and 5\% significance level, respectively) when using the ADF test with a constant and a trend.

\subsection{Reduced-form (structural) consumption functions}

Beginning with the traditional reduced-form consumption function we will start by applying the Kormendi (1983) approach.

\subsubsection{Kormendi approach}

We start by applying the Kormendi (1983) testing procedure of the equivalence. The estimation technique is different from the proposed by the author. Kormendi preferred the estimation of the consumption function in first differences. In this work, an ECM approach representation is used. 
In general, a set of variables $\mathrm{x}_{\mathrm{t}}=\left(\mathrm{x}_{1 \mathrm{t}}, \mathrm{x}_{2 \mathrm{t}}, \ldots, \mathrm{x}_{\mathrm{nt}}\right)$, are said to be co-integrated of order $\mathrm{d}, \mathrm{b}$, denoted by $\mathrm{x}_{\mathrm{t}} \sim \mathrm{CI}(\mathrm{d}, \mathrm{b})$ if:

1. All components of $x_{t}$ are integrated of order $d$.

2. There exists a vector $\beta=\left(\beta_{1}, \beta_{2}, \ldots, \beta_{n}\right)$ such that the linear combination $\beta . x_{t}=\beta_{1} x_{1 t}+\beta_{2} x_{2 t}+\ldots+\beta_{n} x_{n t}$ is integrated of order $(d-b)$, where $b>0$.

The vector $\beta$ is called the co-integrating vector (see Enders, 1995).

When a set of variables is co-integrated their time paths are influenced by the amount of any deviation from long-run equilibrium. The series cannot move independently of each other. When there is a deviation from the long-run equilibrium, and the system is to return to the long-run equilibrium, at least one of the variables must respond to the magnitude of the disequilibrium. Which is the same to say that there is an error correction representation of such variables.

The two-step method of Engle and Granger is used. The first step consists in estimating the proposed consumption function in levels. According to the ADF test results, it is reasonable to assume that all relevant variables for this consumption function are integrated of order one. If those variables are co-integrated than the residual of estimating them in levels is stationary. The application of the ADF test to those presents a value of -6.39 . The critical value of Mackinnon $(1991)^{32}$ is -5.119 . Therefore, the null of no co-integration is rejected. The use of Johansen's (1988) maximum likelihood estimation procedure with two lags in the VAR also rejects the absence of co-integration $^{33}$.

The next step is the estimation of the ECM model. The ECM specification has several advantages. Firstly, it is a dynamic specification, which in general avoids problems of serial correlation. Secondly, when co-integration is present estimating a VAR in first differences is inappropriate. The omission of the ECM term entails a misspecification error (Enders, 1995: 367-8). Thirdly, it avoids the drawback of the high correlation among the levels of the independent variables that could lead to a multicollinearity problem.

\footnotetext{
${ }^{32}$ This critical value is obtained considering $\mathrm{n}=6$, a constant and no trend, and is based on a response surface model.

${ }^{33}$ The Johansen's likelihood ratio test of the null hypothesis of zero co-integration relations against the alternative of one relation has the value of 64.03. The trace test has the value of 225.18 . The critical values at the $10 \%$ significance level are respectively 32.26 and 149.99 (with $\mathrm{h}=8$ ). At the 5\% level the trace critical value is 155.748 . The trace statistic critical values were calculated by Bent Nielsen and are based on 100.000 replications for 400 observations (see Hansen and Juselius, 1995: 79).
} 
The results are the following:

$$
\begin{array}{rlllll}
\mathrm{DC}_{\mathrm{t}}=-0.932 & +0.769 \Sigma \text { DGDP }_{\mathrm{t}} & +0.755 \mathrm{DG}_{\mathrm{t}} & -0.063 \mathrm{DW}_{\mathrm{t}} & +0.990 \text { DTRANSFERS }_{\mathrm{t}} & -0.248 \mathrm{DTX}_{\mathrm{t}} \\
(0.442) & (7.581) & (1.784) & (1.789) & (2.894) & \\
& & &
\end{array}
$$

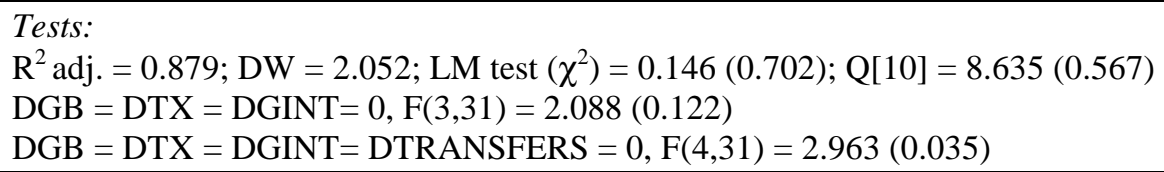

Note: Absolute values of T statistics of the coefficients in brackets. For the tests results the marginal significance levels are presented in brackets. The LM test is a test for first order serial correlation (the null is no serial correlation). The Ljung-Box Q-statistic tests for higher-order serial correlation. The number of correlations used is in brackets. All variables are expressed in per capita real terms.

Under the consolidated approach taxes, government debt and government interest payments on outstanding debt have no effect on private consumption. These implications were tested. The restrictions are accepted by the data, which could be interpreted as evidence in favour of the consolidated approach. A proper test of this approach considers that the equivalence also implies the non-significance of the transfers (which may be seen as a negative tax). When using this definition, the nonsignificance of the variables is rejected. This result is due to the high and statistically significant value of the transfers (it is almost unitary).

The standard (Keynesian) approach sustains that the government expenditure variable (G) has no effect on private consumption. This claim is accepted at the $5 \%$ significance level. According to some authors, Ricardian equivalence implies that consumption is negatively affected by government spending. This is not the case here: government expenditure has a positive sign. However, even in a Ricardian world it is possible to find explanations for a positive sign (or non statistically significant value) for G. Part of government spending is for collective goods which increase the productive capacity of the country, and therefore can be expected to have a positive effect on output. Hence, as in $\mathrm{G}$ we have both productive and 'unproductive' expenditures, a mixed result can be expected.

The tests were also conducted for the long-run relationship. The conclusions were similar to the ones presented above: the consolidated approach restrictions are accepted when the transfers are not considered, but when they are taken into account the consolidated approach is rejected. According to the standard approach the government expenditures are not statistically different from zero.

The results do not seem to confirm the presence of the equivalence in the Portuguese economy. Moreover, the specification does not seem to provide a good description of the data. At the usual 5\% significant level, the only statistically significant variables are GDP, the transfers and the ECM term. 


\subsubsection{Modigliani}

The Modigliani and Sterling (1986) specification requires long lags (5 years) for the disposable income and deficit variables to approximate permanent income. However, when using that specification, those long lags are not statistically significant. ${ }^{34}$ If the number of lags is reduced to just one, the above-mentioned problem of nonsignificance is overcame but the specification violates the initial derivation assumptions. It is no longer an approximation of the permanent income hypothesis. Therefore, we decided not to report the results of the use of this specification, as it did not provide a good fit to the data.

\subsubsection{Bernheim}

We also estimated the equations referred by Bernheim (1987a) but the results were not conclusive. The results for equation 4 were mixed. The pure Keynesian view was rejected. The government surplus was not found to be statistically significant, which is in line with the equivalence hypothesis. However, government consumption presented a statistically significant positive sign, which is against the equivalence proposition. There were also problems of first order serial correlation that could not be solved by incorporating a lag of the dependent variable as a regressor. The unemployment rate and the CPI inflation rate were used as socio-economic indicators.

Equation 3 is very similar to the one estimated by Pereleman and Pestieau (1993). However the latter seems to be preferable to the former. In the former when Ricardian equivalence holds we get:

$$
\mathrm{C}_{\mathrm{t}}=\alpha_{0}+\alpha_{1}\left(\mathrm{Y}_{\mathrm{t}}-\mathrm{G}_{\mathrm{t}}\right)-\alpha_{1} \mathrm{r}_{\mathrm{t}} \mathrm{GB}_{\mathrm{t}}+\alpha_{3} \mathrm{G}_{\mathrm{t}}+\alpha_{4} \mathrm{~GB}_{\mathrm{t}}+\alpha_{5} \mathrm{~W}_{\mathrm{t}}+\mathrm{X}_{\mathrm{t}} \bar{\alpha}+\xi_{\mathrm{t}}
$$

i.e., we get two terms with the public consumption, while according to the pure equivalence view the term in $\alpha_{3}$ should not exist. Therefore, we report instead the results of the specification of Pereleman and Pestieau (1993).

\subsubsection{Pereleman and Pestieau (1993) approach}

The authors propose the estimation of the following equation:

$\mathrm{C}=\alpha_{0}+\alpha_{1}(\mathrm{GDP}-\mathrm{TX})+\alpha_{2} \mathrm{DEF}+\alpha_{3} \mathrm{~W}+\alpha_{4} \mathrm{~GB}+\varepsilon_{\mathrm{t}}$

In the empirical estimation the taxes were defined has the sum of income taxes and social security contributions. The equation proposed was estimated as an ECM model. As the equation above is not a co-integrating vector, the ECM term was calculated as the residual in the relationship between consumption, GDP and the government deficit. ${ }^{35}$ The results for the Portuguese economy were the following:

\footnotetext{
${ }^{34}$ Moreover, this specification is affected by serial correlation.

${ }^{35}$ The ADF test of the residuals of this equation present a value of -3.889 , and the Mackinnon critical value at the $10 \%$ level is -3.595 . Thus co-integration is not rejected at the $10 \%$ significance level.
} 


$$
\begin{aligned}
& \mathrm{DC}_{\mathrm{t}}=-3.125+0.471 \mathrm{D}(\mathrm{GDP}-\mathrm{TX})_{\mathrm{t}}-0.063 \mathrm{DDEF}_{\mathrm{t}}+0.109 \mathrm{DW} 2_{\mathrm{t}}+0.033 \mathrm{DGB}_{\mathrm{t}}-0.342 \mathrm{ECM}_{\mathrm{t}-1} \\
& \begin{array}{lllll}
(1.064) & (4.713) & (0.541) & (3.205) & (0.606)
\end{array}
\end{aligned}
$$

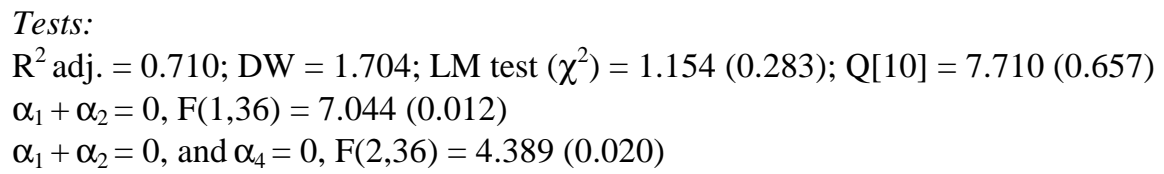

Note: Absolute values of $\mathrm{T}$ statistics of the coefficients in brackets. For the tests results the marginal significance levels are presented in brackets. The LM test is a test for first order serial correlation (the null is no serial correlation). The Ljung-Box Q-statistic tests for higher-order serial correlation. The number of correlations used is in brackets. All variables are expressed in per capita real terms.

There is no serial first order correlation and the signs of the variables are all as expected. Changes in consumption are positively influenced by the net income and wealth. The deficit variable has a statistically non-significant negative impact on consumption. The changes in public debt have also a statistically non-significant positive impact on changes in consumption. consequently, the equivalence hypothesis, which sustains that $\alpha_{1}+\alpha_{2}=0$ and $\alpha_{4}=0$ is rejected by the data. Also rejected is the single restriction implied by the equivalence proposition that the coefficient of the net income is symmetrical of those of deficit.

The symmetric of the sum of the coefficients of the net income and the deficit is 0.408 . That sum may be interpreted as an index of partial equivalence.

To check the sensibility of the results to the proxy of wealth used, we estimated the equation without that proxy and without the public debt variable. Overall, the conclusions remained unaltered: the deficit variable continues to present a negative sign, and continues without being statistically significant.

In short, this specification leads to the conclusion that the substitution of tax for deficit has a positive effect on private consumption in the Portuguese economy. The restrictions imposed by the equivalence proposition are rejected by the data.

\subsection{Euler equation approach}

As mentioned before, the Euler equation approach has the advantage of being explicitly based on the inter-temporal optimisation problem, which enables to test directly two sources of deviation from Ricardian equivalence: the finiteness of the planning horizon and the excess sensitivity of consumption to current income.

\subsubsection{Econometric issues}

As the error term of the derived consumption equation has a first-order moving average structure, MA(1), it would be recommended to use the Generalised Method of Moments (GMM) estimator with twice-lagged variables as instruments. A difficult step is always the choice of the proper instrument variables, being the usual practice simply the use lags of the regressors. However, there were some practical problems in the 
implementation of GMM to this problem. For this particular data set, the Hansen's Jtest $^{36}$ only accepted a choice of instruments such that there was only one more instrument than the number of variables. Moreover, this choice conducted to very imprecise parameter estimates. Hence, we decided to estimate the model by non-linear least squares, using an estimation technique to compute regression standard errors and covariance matrix allowing and correcting for heteroscedasticity and serial correlation of the residuals up to a moving average of one. ${ }^{37,38}$

In order to proceed to estimation in levels of the variables it is necessary to have a cointegration relationship among the non-stationary regressors. This hypothesis is tested using Johansen's maximum likelihood procedure.

Table 3- Johansen's maximum likelihood tests for co-integration for equation 17 - [c, g, linc]

\begin{tabular}{llcrcrcc}
\hline & \multicolumn{3}{c}{ Trace } & \multicolumn{3}{c}{$\lambda$ max } \\
\hline Eigenvalue & $\begin{array}{c}\text { Null } \\
\text { hypothesis }\end{array}$ & H1 & Trace & $\begin{array}{c}5 \% \text { Critical } \\
\text { Value }\end{array}$ & H1 & $\lambda$ max & $\begin{array}{c}5 \% \text { Critical } \\
\text { Value }\end{array}$ \\
\hline 0.5051 & $\mathrm{r}=0$ & $\mathrm{r}=1$ & 37.29 & 29.68 & $\mathrm{r} \geq 1$ & 28.84 & 20.97 \\
0.1779 & $\mathrm{r} \leq 1$ & $\mathrm{r}=2$ & 8.45 & 15.41 & $\mathrm{r} \geq 2$ & 8.03 & 14.07 \\
0.0102 & $\mathrm{r} \leq 2$ & $\mathrm{r}=3$ & 0.42 & 3.76 & $\mathrm{r} \geq 3$ & 0.42 & 3.76 \\
\hline
\end{tabular}

Note: A lag length of three is used on the VAR to remove autocorrelation in the residuals. Critical values for the trace and maximum likelihood tests are from Osterwald-Lenum (1992).

Both the $\lambda_{\max }$ and trace statistic of Johansen's procedure are likelihood ratio (LR) tests, which vary due to the different specifications of the alternative hypothesis. The trace statistic tests the hypothesis that there are at most $r$ co-integrating vectors, whereas the $\lambda_{\max }$ statistic tests the hypothesis of $r+1$ co-integrating vectors given $r$ co-integrating vectors.

As can be concluded from those three tables (Table 3 to Table 5), the existence of at least one co-integrating vector could not be rejected for all proposed set of regressors. Consequently, the estimation in levels could be applied.

Table 4- Johansen's maximum likelihood tests for co-integration for equation 23- [c, g, y, gb]

\begin{tabular}{lccccccc}
\hline & \multicolumn{4}{c}{ Trace } & \multicolumn{3}{c}{$\lambda$ max } \\
\hline Eigenvalue & H0 & H1 & Trace & 5\% Critical Value & H1 & $\lambda$ max & $5 \%$ Critical Value \\
\hline 0.6725 & $\mathrm{r}=0$ & $\mathrm{r}=1$ & 76.60 & 47.21 & $\mathrm{r} \geq 1$ & 45.76 & 27.07 \\
0.4294 & $\mathrm{r} \leq 1$ & $\mathrm{r}=2$ & 30.83 & 29.68 & $\mathrm{r} \geq 2$ & 23.00 & 20.97 \\
0.1656 & $\mathrm{r} \leq 2$ & $\mathrm{r}=3$ & 7.83 & 15.41 & $\mathrm{r} \geq 3$ & 7.42 & 14.07 \\
0.0099 & $\mathrm{r} \leq 3$ & $\mathrm{r}=4$ & 0.41 & 3.76 & $\mathrm{r} \geq 4$ & 0.41 & 3.76 \\
\hline
\end{tabular}

Note: See Table 3.

\footnotetext{
${ }^{36}$ As the number of instruments must be equal or larger than the number of regressors, the Hansen's $\mathbf{J}$ test evaluates the validity of the over-identifying restrictions.

37 The results were obtained using the program Winrats, with the instruction NLLS and the options "robusterrors, lag = 1", and when computationally required for some hypothesis tests also with the option "damp = 1". This options yield Hansen (1982) and White (1980) consistent estimators for the covariance matrix of estimators in the presence of heteroscedasticity and serial correlation.

38 The results and conclusions obtained when used a longer set of instruments were similar to the reported ones.
} 
Table 5- Johansen's maximum likelihood tests for co-integration for equation 25 - [c, g, linc, y, gb]

\begin{tabular}{lccccccc}
\hline & \multicolumn{3}{c}{ Trace } & \multicolumn{3}{c}{$\lambda$ max } \\
\hline Eigenvalue & $\mathrm{H} 0$ & $\mathrm{H} 1$ & Trace & $5 \%$ Critical Value & $\mathrm{H} 1$ & $\lambda$ max & $5 \%$ Critical Value \\
\hline 0.7403 & $\mathrm{r}=0$ & $\mathrm{r}=1$ & 121.88 & 68.52 & $\mathrm{r} \geq 1$ & 55.28 & 33.46 \\
0.5346 & $\mathrm{r} \leq 1$ & $\mathrm{r}=2$ & 66.60 & 47.21 & $\mathrm{r} \geq 2$ & 31.36 & 27.07 \\
0.3694 & $\mathrm{r} \leq 2$ & $\mathrm{r}=3$ & 35.24 & 29.68 & $\mathrm{r} \geq 3$ & 18.91 & 20.97 \\
0.2984 & $\mathrm{r} \leq 3$ & $\mathrm{r}=4$ & 16.33 & 15.41 & $\mathrm{r} \geq 4$ & 14.53 & 14.07 \\
0.0431 & $\mathrm{r} \leq 4$ & $\mathrm{r}=5$ & 1.80 & 3.76 & $\mathrm{r} \geq 5$ & 1.80 & 3.76 \\
\hline
\end{tabular}

Note: See Table 3.

\subsubsection{Results of the generalised permanent income model}

The estimations were made using the usual assumption that $r=\delta=3 \%$. The estimation included also a dummy for the period 1975-1977 to capture the changes implied by the April 1974 revolution. The conclusions are robust to the omission of that dummy. As mentioned before, this model enables us to determine if a departure from Ricardian equivalence is due to differences between the planning horizon of consumers and the government. When $\gamma$ is less than one, consumers have a shorter planning horizon than the government, and government bonds are regarded as net wealth.

Table 6- NLLS estimation of equation 17- Permanent Income Model

\begin{tabular}{lccccc}
\hline & $\beta_{1}$ & $\gamma$ & $\theta$ & Wald test & $\mathrm{R}^{2}$ adj \\
\hline Unrestricted & 1.401 & 0.995 & -3.669 & & 0.9976 \\
& $(8.11)$ & $(145.2)$ & $(38.9)$ & & \\
Restrictions & & & & & \\
$\gamma=1$ & 1.404 & & -3.733 & 0.5296 & 0.9977 \\
& $(9.19)$ & & $(13.59)$ & $(0.47)$ & \\
$\theta=0$ & 0.704 & 0.974 & & 195.38 & 0.995 \\
& $(3.92)$ & $(28.24)$ & & $(0.00)$ & \\
$\gamma=1, \theta=0$ & 0.651 & & 196.6 & 0.995 \\
& $(4.05)$ & & $(0.0)$ & \\
\hline
\end{tabular}

Notes: Annual data from 1954 to 1997, 38 degrees of freedom. Estimation by non-linear least squares. Heteroscedasticity and autocorrelation consistent t-statistics in parentheses. The Wald test is for the validity of the imposed restriction (marginal significance level in parentheses). A dummy for the period 1975-1977 is included, but its results are not reported. Unless otherwise stated $\mathrm{r}$ is set at $3 \%$. The initial conditions for all estimations were: $\beta_{1}=$ $0.3 ; \gamma=0.5 ; \theta=0.3 ; \lambda=0.6$; and the dummy coefficient $=0.6$.

The parameter estimate of $\gamma$ is close to unity and statistically significant. The Wald test does not reject the null of an infinite planning horizon $(\gamma=1)$ for the Portuguese economy.

The sign of $\theta$ has implications for the relation between government consumption and private consumption. In this case $\theta$ is statistically significant and negative, meaning that an increase in government consumption increases the marginal utility of private consumption (i.e., there is a complementarity between the two). Hence, the results do not confirm the hypothesis that government consumption crowds out private consumption. 
The joint restriction $\gamma=1, \theta=0$ is rejected by the data. Thus, these results appear to be in line with the infinite horizon permanent income model, but with one major empirical inconsistency: the parameter estimates for $\beta_{1}$ are excessively high, and even larger than the unity.

This economically impossible high propensity to consume out of total expected wealth could be the result of measurement errors in the consumption and disposable labour income data, inadequacy of the model (i.e., of the mathematical solution used to eliminate non-labour income), or the result of liquidity constraints. A liquidityconstrained consumer has a limited possibility for inter-temporal consumption smoothing, which increases the sensitivity of consumption to current income. This hypothesis is examined in the next section.

Due to this inconsistency we find the empirical results presented as inconclusive with regard to testing the Ricardian equivalence proposition.

\subsubsection{Results of the generalised permanent income model and the excess sensitivity hypothesis}

The previous model is extended by incorporating the possibility of the existence of liquidity-constrained (rule-of-thumb) consumers. $\lambda$ denotes the fraction of disposable income that goes to liquidity constrained (rule-of-thumb) consumers. If that fraction is significant, than government deficits have real effects, even if other consumers optimize over an infinite horizon $(\gamma=1)$. The following table summarizes the results.

Table 7- NLLS estimation of equation 20 - Permanent Income Model with Excess Sensitivity to Current Income

\begin{tabular}{lcccccc}
\hline & $\beta_{1}$ & $\gamma$ & $\theta$ & $\lambda$ & Wald test & $\mathrm{R}^{2}$ adj \\
\hline Unrestricted & 1.425 & 0.996 & -3.904 & 0.122 & & 0.9977 \\
& $(8.12)$ & $(158.3)$ & $(16.62)$ & $(1.72)$ & & \\
Restrictions & & & & & \\
$\lambda=0$ & 1.401 & 0.995 & -3.669 & & 1.718 & 0.9976 \\
& $(8.11)$ & $(145.2)$ & $(38.9)$ & & $(0.09)$ & \\
$\gamma=1$ & 1.4275 & & -3.964 & 0.124 & 0.36 & 0.9978 \\
& $(8.08)$ & & $(19.01)$ & $(1.84)$ & $(0.55)$ & \\
$\theta=0$ & 0.793 & 0.982 & & 0.337 & 133.58 & 0.9954 \\
& $(3.57)$ & $(35.11)$ & & $(2.28)$ & $(0.0)$ & \\
$\gamma=1, \theta=0$, & 0.651 & & & 149.2 & 0.995 \\
$\lambda=0$ & $(3.57)$ & & & & $(0.0)$ & \\
\hline
\end{tabular}

Notes: see Table 6.

Once again the hypothesis of an infinite planning horizon $(\gamma=1)$ cannot be rejected. The parameter estimate for the excess sensitivity of consumption to current income $(\lambda)$ is relatively small and is only statistically significant at the $10 \%$ significance level. The parameter estimates for $\beta_{1}$ continues to be excessively large in the presence of an infinite planning horizon. This coefficient is even slightly larger than in the previous case (where $\lambda=0$ ).

The joint restriction $\gamma=1, \theta=0, \lambda=0$ is rejected by the data. 
When the restriction of an infinite planning horizon is imposed, the parameter estimate for $\lambda$ is almost unaltered but its t-statistic improves (the marginal significance level of the null hypothesis decreases from $8.5 \%$ to $6.6 \%$ ).

Once again, due to the high value of the propensity to consume out of total expected wealth $\left(\beta_{1}\right)$ we find the results inconclusive regarding the Ricardian equivalence view. It could also be that the assumption that the proportion of rule-of-thumb consumers is constant over time is invalid. $\lambda$ is expected to vary with the degree of creditworthiness

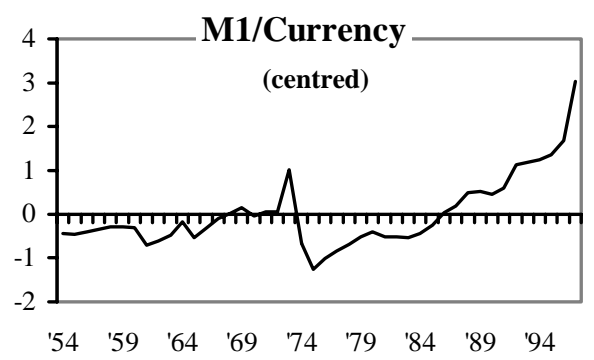
of consumers and is likely to be affected with structural changes in financial markets. However, none of these reasons is directly observable, and it is very difficult to find adequate proxies for those phenomena. Brunila (1997) used the unemployment rate, and the stock of private sector credit to GDP as proxy for variations in consumer's creditworthiness and for financial deregulation, respectively. For the Portuguese income those proxies are not satisfactory. In the early 1980's there were tight government financial controls, and for the same period the second mentioned proxy reached an historic maximum. Alternatively we tried to capture the degree of financial deregulation by the centred value of the ratio of M1 over currency (m1c), substituting $\lambda$ by $\left[\lambda+\lambda_{1}(\mathrm{~m} 1 \mathrm{c})\right]$. The evolution of that variable can be seen in the next figure.

The results of the extended model were the following:

Table 8- NLLS estimation of equation 20 with $\lambda+\lambda_{1}(\mathrm{~m} 1 \mathrm{c})$ - Permanent Income Model with Excess Sensitivity to Current Income

\begin{tabular}{cccccccccc}
\hline \multicolumn{1}{c}{ Unrestricted estimates } & \multicolumn{4}{c}{ Wald test } \\
\hline$\beta_{1}$ & $\gamma$ & $\theta$ & $\lambda$ & $\lambda_{1}$ & $\mathrm{R}^{2}$ adj & $\gamma=1$ & $\lambda=0$ & $\lambda_{1}=0$ & $\lambda=\lambda_{1}=0$ \\
\hline 1.397 & 0.999 & -3.997 & 0.135 & 0.084 & 0.9977 & 0.009 & 4.774 & 3.299 & 43.667 \\
$(8.18)$ & $(141.0)$ & $(12.78)$ & $(2.18)$ & $(1.81)$ & & $(0.93)$ & $(0.03)$ & $(0.07)$ & $(0.0)$ \\
\hline
\end{tabular}

Notes: see Table $6 . \mathrm{m} 1 \mathrm{c}$ is the centred value of ratio of M1 over currency.

Using this specification, $\lambda$ becomes statistically significant at the $5 \%$ significance level, while $\lambda_{1}$ is only significant at the $10 \%$ significance level. It should however be mentioned that the results are very sensitive to the proxy used. As the quality of the proxy cannot be certified the results must be interpreted with caution.

An infinite planning horizon could not be rejected. Nevertheless, the parameter estimate for $\beta_{1}$ continues to be excessively high. It is almost unchanged from its impossibly high value found in previous estimations, denoting the persistence of an inconsistency in the model.

Under excess sensitivity private consumption is not invariant to changes in government fiscal policy, leading to a failure of Ricardian equivalence. It appears to be reasonable to conclude that this is the case for the Portuguese economy. 


\subsubsection{Results of the permanent income model with a consolidated government sector}

This specification arises when rational consumers incorporate the government solvency condition in their optimisation problem. The results of this more restrictive (more Ricardian) model are given in Table 9.

Table 9- NLLS estimation of equation 23- Permanent Income Model with a Consolidated Government Sector

\begin{tabular}{lllllll}
\hline \multicolumn{3}{c}{ Unrestricted estimates } & \multicolumn{3}{c}{ Wald test } \\
\hline$\beta_{1}$ & $\gamma$ & $\theta$ & $\mathrm{R}^{2}$ adj & $\gamma=1$ & $\theta=0$ & $\gamma=1$, \\
& & & & & & $\theta=0$ \\
\hline 1.401 & 0.998 & -3.6785 & 0.9976 & 0.264 & 193.4 & 196.7 \\
$(8.039)$ & $(237.3)$ & $(44.13)$ & & $(0.608)$ & $(0.0)$ & $(0.0)$ \\
\hline
\end{tabular}

Notes: see Table 6. Differently from the previous estimations the income variable is pre-tax labour income.

The Ricardian neutrality proposition implies an infinite planning horizon $(\gamma=1)$, when consumers discount taxes, government transfer payments, and government consumption at the same rate as the government. If consumers have a shorter time horizon, i.e. $0<\lambda<1$, then they discount future taxes at the rate $\lambda /(1+r)$, which is smaller than the one for the government $1 /(1+r)$.

The results of this pro-Ricardian specification are not very different from the previous ones. It is not possible to reject the null of an infinite planning horizon, which is in favour of equivalence. The substitutability parameter $(\theta)$ is once again statistically different from zero, implying that public and private consumption are complementary, and that public consumption influences positively the private consumption.

The estimated value for $\beta_{1}$ continues however to be impossibly higher. Once again it could be the result of excess sensibility of consumption to current income. This is the subject of the next specification.

Table 10- NLLS estimation of equation 25- Permanent Income Model with a Consolidated Government Sector and Excess Sensitivity

\begin{tabular}{|c|c|c|c|c|c|c|c|c|}
\hline \multicolumn{5}{|c|}{ Unrestricted estimates } & & \multicolumn{3}{|c|}{ Wald test } \\
\hline & $\beta_{1}$ & $\gamma$ & $\theta$ & $\lambda$ & $\mathrm{R}^{2}$ adj & $\gamma=1$ & $\lambda=0$ & $\gamma=1, \lambda=0$ \\
\hline$r=0.03$ & $\begin{array}{c}0.333 \\
(2.262)\end{array}$ & $\begin{array}{c}2.169 \\
(3.625)\end{array}$ & $\begin{array}{c}0.134 \\
(0.961)\end{array}$ & $\begin{array}{c}0.624 \\
(4.184)\end{array}$ & 0.9959 & $\begin{array}{c}3.815 \\
(0.051)\end{array}$ & $\begin{array}{l}17.505 \\
(0.0)\end{array}$ & $\begin{array}{l}21.478 \\
(0.0)\end{array}$ \\
\hline $\mathrm{r}=0.01$ & $\begin{array}{c}0.312 \\
(2.167)\end{array}$ & $\begin{array}{c}2.256 \\
(3.227)\end{array}$ & $\begin{array}{c}0.156 \\
(1.145)\end{array}$ & $\begin{array}{c}0.645 \\
(4.387)\end{array}$ & 0.9959 & $\begin{array}{c}3.228 \\
(0.072)\end{array}$ & $\begin{array}{c}19.248 \\
(0.0)\end{array}$ & $\begin{array}{l}26.330 \\
(0.0)\end{array}$ \\
\hline$r=0.05$ & $\begin{array}{c}0.352 \\
(2.344)\end{array}$ & $\begin{array}{c}2.099 \\
(4.072)\end{array}$ & $\begin{array}{c}0.110 \\
(0.761)\end{array}$ & $\begin{array}{r}0.604 \\
(4.014)\end{array}$ & 0.9959 & $\begin{array}{c}4.547 \\
(0.033)\end{array}$ & $\begin{array}{l}16.115 \\
(0.0)\end{array}$ & $\begin{array}{l}17.931 \\
(0.0)\end{array}$ \\
\hline
\end{tabular}

Notes: see Table 6.

When testing the consolidated model with excess sensitivity of consumption to current income, it can be concluded that the excess sensitivity parameter is statistically significant. The results are also robust to several levels for the real interest rate. 
The substitutability parameter $(\theta)$ ceases to be statistically significant and changes its sign. The non-significance means that government consumption does not influence private consumption.

The parameter estimates for $\beta_{1}$ are now significantly lower than in previous regressions, which is more in line with the permanent income hypothesis and is precisely estimated.

A puzzlingly result is the high value for $\gamma$ (larger than 2), which does not finds a plausible economic interpretation and violates the assumptions necessary to derive the model. The implied expected lifetime for individuals is -0.855 years! Due to this inconsistency, this parameter was subsequently restricted to one. The results are presented in Table 11.

Table 11- NLLS estimation of equation 25- Permanent Income Model with a Consolidated Government Sector and Excess Sensitivity when $\gamma$ is restricted to be 1

\begin{tabular}{ccccc}
\hline & $\beta_{1}$ & $\theta$ & $\lambda$ & $\mathrm{R}^{2}$ adj \\
\hline $\mathbf{r}=\mathbf{0 . 0 3}$ & $\mathbf{0 . 8 0 3}$ & $\mathbf{0 . 0 5 6}$ & $\mathbf{0 . 3 6 7}$ & $\mathbf{0 . 9 9 5 4}$ \\
& $\mathbf{( 3 . 7 0 6 )}$ & $\mathbf{( 0 . 8 8 3 )}$ & $\mathbf{( 2 . 6 0 7 )}$ & \\
$\mathrm{r}=0.01$ & 0.788 & 0.144 & 0.423 & 0.9954 \\
& $(3.614)$ & $(1.922)$ & $(3.166)$ & \\
& & & & \\
$\mathrm{r}=0.05$ & 0.827 & -0.098 & 0.267 & 0.9955 \\
& $(3.862)$ & $(0.846)$ & $(1.731)$ & \\
\hline
\end{tabular}

Notes: see Table 6.

When $\gamma$ is restricted to be unity, implying an infinite planning horizon, the parameter estimates for $\beta_{1}$ take up again an inconsistently high value.

The substitutability parameter $(\theta)$ is again not statistically significant, except when the real interest rate is set at $1 \%$. When, as in previous regressions the real interest rate is set at $3 \%$ the government consumption does not influence private consumption.

The estimate results confirm the presence of excess sensitivity of consumption to current income. In the central estimate and when the interest rate is set at the $1 \%$ level, the excess sensitivity parameter $\lambda$ is statistically significant at the $1 \%$ significance level. Even when the real interest is set at the (high) level of 5\% this parameter continues to be statistically significant at the $10 \%$ significance level.

To sum up, this specification appears to point to a failure of Ricardian equivalence due not to a failure of an infinite planning horizon but to the existence of liquidity restraints. The excess sensibility of consumption to current income causes a departure from equivalence. 


\section{Conclusions}

This paper started by reviewing the theoretical requirements of Ricardian equivalence. In order Ricardian equivalence to hold a large number of assumptions should be fulfilled. However, theoretical restrictiveness of Ricardian equivalence does not constitute a practical refutation of its validity. It is necessary to examine the empirical evidence. A brief survey of the most relevant empirical consumption studies on equivalence was done. The empirical work of Kormendi (1983), Modigliani and Sterling (1986), Bernheim (1987a), Pereleman and Pestieau (1993), and Leachman (1996), on the structural consumption functions was reviewed. The work of Cardia (1997), which concluded for the weakness of the usual tests, was also mentioned. A review of the work done on the Euler equation approach was done as well, following the work of (Brunila, 1997).

In the second part of the paper an empirical application to the Portuguese economy was done. The Kormendi (1983) specification is a co-integration relationship; therefore an ECM model was estimated. The test proposed by the author was in line with Ricardian predictions. However, when this test is extend to include the transfers the Ricardian predictions are rejected. The standard (Keynesian) view that public expenditures have no negative influence on consumption is accepted. Thus, this specification appears to find a failure of Ricardian equivalence. Yet, the non-statistical significance of most variables (aside GDP, transfers, and the ECM term), point to the absence of good fit of the model to the data.

When using the Pereleman and Pestieau (1993) approach, the results were against the equivalence: the restrictions implied by the equivalence were rejected by the data. There is only partial equivalence in the Portuguese economy: the substitution of tax for deficit has a positive effect on private consumption.

The second part of the empirical tests focused on the Euler equation approach. This approach has the advantage of enabling to directly test two sources of deviation from Ricardian equivalence: the finiteness of the planning horizon and the excess sensitivity of consumption to current income.

The results of the generalised permanent income model appeared to be in line with the infinite horizon permanent income model, but with one major empirical inconsistency: the parameter estimates for the propensity to consume out of total expected wealth $\left(\beta_{1}\right)$ are excessively high. Due to this inconsistency we find the empirical results presented as inconclusive with regard to testing the Ricardian equivalence proposition.

The results of the generalised permanent income model extended to incorporate the excess sensitivity hypothesis gave partial support for the existence of liquidityconstrained consumers, while still accepting an infinite planning horizon. Once again the results were inconclusive.

When using the pro-Ricardian specification of the permanent income model with a consolidated government sector the results were not very different from the previous ones. In favour of the equivalence an infinite planning horizon could not be rejected. However, the estimates for the $\beta_{1}$ parameter continued to be impossibly high. 
Extending this model to integrate the excess sensitivity of consumption to current income hypothesis, it can be concluded that the excess sensitivity parameter is statistically significant (with a magnitude around 0.6 ). The parameter estimates for $\beta_{1}$ were now significantly lower than in previous regressions. However, the parameter estimate for the planning horizon variable $(\gamma)$ is excessively high. This variable was then restricted to one, i.e. implying an infinite planning horizon. The results confirm the presence of excess sensitivity of consumption to current income. This specification appears to suggest that Ricardian equivalence fails in the Portuguese economy not as a result of a finite planning horizon but due to the presence of liquidity constrained consumers.

All in all, the empirical evidence of Ricardian equivalence based on the consumption function is ambiguous for the Portuguese economy.

\section{References}

BARRO, Robert J. (1974), “Are Government Bonds Net wealth?”, Journal of Political Economy, vol. 82 (6), 1095-117.

BARRo, Robert J. (1989), "The Ricardian Approach to Budget Deficits", Journal of Economic Perspectives, vol. 3 (2), 37-54.

BARTH, James R., George IDEN and Frank S. RuSSEK (1986), "Government Debt, Government Spending, and Private Sector Behavior: Comment", American Economic Review, vol. LXXVI (5), 1158-67.

Bayoumi, Tamim and Paul R Masson (1998), "Liability-creating versus nonliability-creating fiscal stabilization policies: Ricardian equivalence, fiscal stabilization, and EMU”, CEPR Discussion Paper no. 1984, October [Published: The Economic Journal, 108, July, 1026-45].

BERNHEIM, B. Douglas (1987a), "Ricardian Equivalence: an evaluation of theory and evidence" with three 'Comments', in Stanley Fisher (ed.), NBER Macroeconomics Annual 1987, 263-315.

BERNHEIM, B. Douglas, (1987b), "Ricardian Equivalence: an evaluation of theory and evidence", NBER Research Working Paper No. 2330, July.

BlanchaRd, O. J. (1985), "Debt deficits, and Finite Horizons", Journal of Political Economy, 93 (2), 223-47.

Brennan, H. Geoffrey and James M. Buchanan (1986), "The Logic of the Ricardian Equivalence Theorem", in Buchanan, James M. et al. (eds.), Deficits, Oxford, Basil Blackwell, 79-92.

Brunila, Anne (1997), Fiscal Policy and Private Consumption - Saving Decisions: European Evidence, Bank of Finland Studies E: 8. 
Cebula, Richard J., Chao-Shun Hung and Neela D. Manage (1996), "Ricardian Equivalence, Budget Deficits, and Saving in the United States, 1955:1-1991:4", Applied Economics Letters, 3(8), 525-28.

CÉSAR das Neves, João (1994), The Portuguese Economy: a picture in figures XIX and XX centuries, Universidade Católica Editora, Lisboa.

De Grauwe, Paul (1996), International Money, $2^{\text {nd }}$ ed., Oxford, Oxford University Press.

ENDERS, Walter (1995), Applied Econometric Time Series, John Wiley \& Sons, Inc.

Evans, Paul (1993), "Consumers Are Not Ricardian: Evidence from Nineteen Countries”, Economic Inquiry, vol. 31 (4), 534-548.

Evans, Paul (1988), "Are Consumers Ricardian? Evidence for the United States", Journal of Political Economics, vol. 96 (5), 983-1004.

FeldSTEIN, Martin and Douglas W. ElmendorF (1990), "Government Debt, Government Spending, and Private Sector Behavior Revisited: Comment", American Economic Review, 80(3), 589-99.

Flavin, Marjorie (1987), "Comment", in Stanley Fisher (ed.), NBER Macroeconomics Annual 1987, 304-9.

GrahaM, Fred C. (1992), "On the importance of the measurement of consumption in tests of Ricardian equivalence", Economics Letters, vol. 38 (Apr.), 431-34.

GrahaM, Fred C. (1995), "Government Debt, Government Spending, and Private Sector Behavior: Comment", American Economic Review, 85 (5), 1348-56.

HANSEN, L.P. (1982), "Large Sample Properties of Generalized Method of Moments Estimators", Econometrica, 50, 1029-1054.

HaNSEN, Henrik and Katarina JuSELIUS (1995), CATS in RATS: Co-integration Analysis of Time Series, Estima.

Hayashi, Fumio (1982), "The Permanent Income Hypothesis: Estimation and Testing by Instrumental Variables", Journal of Political Economy, 90 (5), 895-916.

Hayashi, Fumio (1987), "Tests for Liquidity Constraints: a critical survey and some new observations", in Truman F. Bewley (ed.), Advances in Econometrics Fifth World Congress, vol. II, Cambridge University Press, 91-120.

JoHANSEN, S. (1988), "Statistical Analysis of Cointegration Vectors", Journal of Economic Dynamics and Control, 12, 231-54.

KoRMENDI, Roger C. (1983), "Government Debt, Government Spending, and Private Sector Behavior", American Economic Review, 73(5), 994-1010. 
Kormendi, Roger C. and Philip Meguire (1990), "Government Debt, Government Spending, and Private Sector Behavior: Reply and Update", American Economic Review, 80(3), 604-617.

LEACHMAN, Lori L. (1996), "New Evidence on the Ricardian Equivalence Theorem: A Multico-integration Approach", Applied Economics, 28(6), 695-704.

MACKInNON (1991), "Critical Values for Co-integration Tests", in R. F. Engle and C.W.J. Granger, ed.s, Long-Run Economic Relationships, London, Oxford, 1991, 267-276.

Modigliani, Franco and Arlie Sterling (1986), "Government Debt, Government Spending, and Private Sector Behavior: Comment", American Economic Review, 76(5), 1168-79.

Osterwald-Lenum, M. (1992), "A Note with Fractiles of the Asymptotic Distribution of the Maximum Likelihood Cointegration Rank Test Statistics: four cases", Oxford Bulletin of Economics and Statistics, 54, 461-72.

Perelman, Sergio and Pierre Pestieau (1993), "The Determinants of the Ricardian Equivalence in the OCDE Countries", in Verbon and Winden (eds.) (1993), 181194.

PoterbA, James, and Lawrence SuMmers (1987), "Finite Lifetimes and the Effects of Budget Deficits on Nation Saving", Journal of Monetary Economics, 20 (September), 369-91.

RICARDO, David (1820), "Funding System" in SRAFFA, Piero (ed.) (1951), The Works and Correspondence of David Ricardo, vol IV: Pamphlets and papers 1815-1823, Cambridge, Cambridge University Press for the Royal Economic Society.

ROMER, David (1996), Advanced Macroeconomics, McGraw Hill.

SANTos, Emanuel (1984), Bens de consumo duradouros; estimativas anuais do stock e do consumo no período 1958-1981, Estudos e Documentos de Trabalho No. 6, Banco de Portugal, Lisbon.

SEATER, John J. (1993), "Ricardian equivalence", Journal of Economic Literature, 31 (1), 142-190.

Seater, Jonh J. and R. S. Mariano (1985), "New Tests of the Life Cycle and Tax Discounting Hypothesis", Jounal of Monetary Economics, 15, 317-21.

STANLEY, T. D. (1998), "New Wine in Old Bottles: A Meta-analysis of Ricardian Equivalence", Southern Economic Journal; 64(3), January, 713-27.

White, H. (1980), "A Heteroskedasticity-Consistent Covariance Matrix Estimator and Direct Test for Heteroskedasticity”, Econometrica, 48, 817-838. 


\section{Annex - Data source}

The data source used in this work is Bank of Portugal, Historical series for the Portuguese economy post - II World war, Vol. I - Statistical Series, Lisbon, 1997. This work presents a consistent set of macroeconomic series for the Portuguese economy for the period 1953-1993.

The series were further updated using the Economic Research and Forecasting Department (DGEP), Ministry of Finance, Statistical Annex to The Portuguese Economy, Lisbon, Portugal, April 1999.

Data is expressed in $10^{6}$ PTE. The data used in the text is expressed in a per capita basis. The deflator of the private consumption was used to obtain the real values of all the budget variables, with the exception of public consumption (for which its own deflator was used). Public debt was deflated using the GDP deflator.

\section{Appendix - A tentative construction of a proxy for the wealth variable for the Portuguese economy}

One of the limitations for the conduct of empirical tests is the availability and quality of economic data. For the Portuguese economy this is a serious problem. There is no data available about capital stock or private sector wealth. This is a major limitation for the realisation of the tests that could be done. That is why we tried to find a proxy for the capital stock and use it in the Ricardian equivalence tests.

The basis of this calculus was the study by Santos (1984). The author calculated a measure of the capital stock for the Portuguese economy for the period 1958-1981. However, the study was not further updated. Following César das Neves (1994) method we tried to update the estimative for the period 1954-1997. This is a rather simplistic and mechanical update that mainly reflects the revision of the series of real investment.

The first year of Santos (1984)'s estimate is 1959. The update procedure was made in six steps:

Step1: the multiplication of the K/Y ratio found by Santos (1984) for $1959-2.7$ - by the revised real GDP gives the value of the real stock of capital for 1959.

Step2: Assuming a depreciation rate $(\mathrm{d})^{39}$, the stock of capital series $(\mathrm{K})$ was extrapolated backwards (1953-1958) using the investment series (I) and the formula:

$\mathrm{K}_{\mathrm{t}-1}=\left[\mathrm{K}_{\mathrm{t}}-\mathrm{I}_{\mathrm{t}}\right] /(1-\mathrm{d})$

Step 3: The following formula is used to calculate the implicit depreciation rates in Santos (1984) series:

$\mathrm{K}_{\mathrm{t}+1}=\mathrm{K}_{\mathrm{t}} \cdot\left(1-\mathrm{d}_{\mathrm{t}}\right)+\mathrm{I}_{\mathrm{t}+1}$

${ }^{39}$ The assumed value was of 3 and $4 \%$ for the series K1 and K2, respectively. 
Step 4: The depreciation rates calculated in the previous step along with the investment series are used to calculate the stock of capital for 1960-1982 using equation (2).

Step 5a: As in César das Neves (1994) a depreciation rate of 4\% is assumed for the period 1982-1997, obtaining series K1.

Step 5b: An auxiliary regression is used to extrapolate the values of the depreciation rate for the period 1982-1997. The equation estimated was:

$\operatorname{Ln} \mathrm{d}=-3.57+0.192 \ln$ trend

(186.8) (23.9) $\quad \mathrm{R}^{2}=96.5 \%$

Step 6: Adding the value of $\mathrm{M}^{-}$to both series of the stock of capital gives rise to a proxy for the wealth of the private sector. Table 12 below presents the results. The differences between both measures are not very significant. The estimate for K2 gives naturally a lower K/GDP ratio for the end of the sample. We prefer the use of K2, as it is more likely that the rate of depreciation has increased gradually over time rather than remained constant. 
Table 12- Capital stock and Wealth proxies estimation

\begin{tabular}{|c|c|c|c|c|c|c|c|c|c|c|c|}
\hline \multirow[b]{2}{*}{ Year } & \multicolumn{2}{|c|}{ Depreciation rates } & \multicolumn{2}{|c|}{ Capital Stock } & \multirow[b]{2}{*}{ M2- } & \multicolumn{2}{|c|}{ Proxy Wealth } & \multicolumn{4}{|c|}{ Ratios } \\
\hline & d1 & d2 & K1 & $\mathbf{K 2}$ & & W1 & W2 & K1/GDP & K2/GDP & W1/GDP & W2/GDP \\
\hline 1954 & 0.04000 & 0.03000 & $4,504,313$ & $4,229,071$ & 901,383 & $5,405,696$ & $5,130,454$ & 2.54 & 2.38 & 3.05 & 2.89 \\
\hline 1955 & 0.04000 & 0.03000 & $4,718,107$ & $4,496,166$ & 938,420 & $5,656,527$ & $5,434,586$ & 2.58 & 2.46 & 3.09 & 2.97 \\
\hline 1956 & 0.04000 & 0.03000 & $4,963,857$ & $4,795,755$ & 971,076 & $5,934,933$ & $5,766,831$ & 2.62 & 2.53 & 3.13 & 3.04 \\
\hline 1957 & 0.04000 & 0.03000 & $5,248,995$ & $5,135,575$ & $1,036,241$ & $6,285,236$ & $6,171,816$ & 2.65 & 2.59 & 3.17 & 3.11 \\
\hline 1958 & 0.04000 & 0.03000 & $5,580,199$ & $5,522,672$ & $1,109,562$ & $6,689,761$ & $6,632,233$ & 2.65 & 2.63 & 3.18 & 3.15 \\
\hline 1959 & 0.03106 & 0.03106 & $5,914,337$ & $5,914,337$ & $1,161,785$ & $7,076,122$ & $7,076,122$ & 2.70 & 2.70 & 3.23 & 3.23 \\
\hline 1960 & 0.03172 & 0.03172 & $6,290,787$ & $6,290,787$ & $1,220,558$ & $7,511,345$ & $7,511,345$ & 2.74 & 2.74 & 3.28 & 3.28 \\
\hline 1961 & 0.03372 & 0.03372 & $6,747,146$ & $6,747,146$ & $1,241,057$ & $7,988,203$ & $7,988,203$ & 2.84 & 2.84 & 3.36 & 3.36 \\
\hline 1962 & 0.03555 & 0.03555 & $7,172,186$ & $7,172,186$ & $1,375,222$ & $8,547,407$ & $8,547,407$ & 2.73 & 2.73 & 3.26 & 3.26 \\
\hline 1963 & 0.03716 & 0.03716 & $7,496,374$ & $7,496,374$ & $1,570,563$ & $9,066,937$ & $9,066,937$ & 2.75 & 2.75 & 3.33 & 3.33 \\
\hline 1964 & 0.03859 & 0.03859 & $7,855,436$ & $7,855,436$ & $1,792,641$ & $9,648,077$ & $9,648,077$ & 2.72 & 2.72 & 3.34 & 3.34 \\
\hline 1965 & 0.03996 & 0.03996 & $8,284,102$ & $8,284,102$ & $1,858,929$ & $10,143,031$ & $10,143,031$ & 2.62 & 2.62 & 3.20 & 3.20 \\
\hline 1966 & 0.04121 & 0.04121 & $8,834,359$ & $8,834,359$ & $2,072,808$ & $10,907,167$ & $10,907,167$ & 2.67 & 2.67 & 3.29 & 3.29 \\
\hline 1967 & 0.04217 & 0.04217 & $9,345,488$ & $9,345,488$ & $2,226,102$ & $11,571,590$ & $11,571,590$ & 2.71 & 2.71 & 3.35 & 3.35 \\
\hline 1968 & 0.04360 & 0.04360 & $9,881,863$ & $9,881,863$ & $2,503,941$ & $12,385,804$ & $12,385,804$ & 2.72 & 2.72 & 3.41 & 3.41 \\
\hline 1969 & 0.04472 & 0.04472 & $10,504,032$ & $10,504,032$ & $2,764,013$ & $13,268,044$ & $13,268,044$ & 2.82 & 2.82 & 3.57 & 3.57 \\
\hline 1970 & 0.04584 & 0.04584 & $11,134,035$ & $11,134,035$ & $3,099,414$ & $14,233,449$ & $14,233,449$ & 2.76 & 2.76 & 3.53 & 3.53 \\
\hline 1971 & 0.04686 & 0.04686 & $11,948,763$ & $11,948,763$ & $3,553,487$ & $15,502,249$ & $15,502,249$ & 2.68 & 2.68 & 3.47 & 3.47 \\
\hline 1972 & 0.04786 & 0.04786 & $12,996,355$ & $12,996,355$ & $4,075,647$ & $17,072,001$ & $17,072,001$ & 2.63 & 2.63 & 3.46 & 3.46 \\
\hline 1973 & 0.04883 & 0.04883 & $14,126,114$ & $14,126,114$ & $4,663,502$ & $18,789,616$ & $18,789,616$ & 2.73 & 2.73 & 3.63 & 3.63 \\
\hline 1974 & 0.04950 & 0.04950 & $15,298,475$ & $15,298,475$ & $4,613,281$ & $19,911,756$ & $19,911,756$ & 2.86 & 2.86 & 3.73 & 3.73 \\
\hline 1975 & 0.04996 & 0.04996 & $16,011,775$ & $16,011,775$ & $4,217,989$ & $20,229,763$ & $20,229,763$ & 3.15 & 3.15 & 3.98 & 3.98 \\
\hline 1976 & 0.05035 & 0.05035 & $16,590,088$ & $16,590,088$ & $4,256,684$ & $20,846,771$ & $20,846,771$ & 3.18 & 3.18 & 4.00 & 4.00 \\
\hline 1977 & 0.05061 & 0.05061 & $17,411,418$ & $17,411,418$ & $4,105,511$ & $21,516,929$ & $21,516,929$ & 3.14 & 3.14 & 3.88 & 3.88 \\
\hline 1978 & 0.05075 & 0.05075 & $18,127,181$ & $18,127,181$ & $4,270,004$ & $22,397,185$ & $22,397,185$ & 3.07 & 3.07 & 3.79 & 3.79 \\
\hline 1979 & 0.05064 & 0.05064 & $19,021,955$ & $19,021,955$ & $4,735,564$ & $23,757,520$ & $23,757,520$ & 3.00 & 3.00 & 3.74 & 3.74 \\
\hline 1980 & 0.05057 & 0.05057 & $19,777,413$ & $19,777,413$ & $4,922,556$ & $24,699,970$ & $24,699,970$ & 2.96 & 2.96 & 3.70 & 3.70 \\
\hline 1981 & 0.05042 & 0.05042 & $20,756,517$ & $20,756,517$ & $5,226,076$ & $25,982,594$ & $25,982,594$ & 3.02 & 3.02 & 3.78 & 3.78 \\
\hline 1982 & 0.05000 & 0.05199 & $21,734,282$ & $21,734,282$ & $5,521,395$ & $27,255,677$ & $27,255,677$ & 3.07 & 3.07 & 3.85 & 3.85 \\
\hline 1983 & 0.05000 & 0.05239 & $22,623,297$ & $22,580,118$ & $5,145,046$ & $27,768,343$ & $27,725,164$ & 3.14 & 3.13 & 3.85 & 3.85 \\
\hline
\end{tabular}




\begin{tabular}{|c|c|c|c|c|c|c|c|c|c|c|c|}
\hline \multirow[b]{2}{*}{ Year } & \multicolumn{2}{|c|}{ Depreciation rates } & \multicolumn{2}{|c|}{ Capital Stock } & \multirow[b]{2}{*}{ M2- } & \multicolumn{2}{|c|}{ Proxy Wealth } & \multicolumn{4}{|c|}{ Ratios } \\
\hline & d1 & d2 & K1 & K2 & & W1 & W2 & K1/GDP & K2/GDP & W1/GDP & W2/GDP \\
\hline 1984 & 0.05000 & 0.05279 & $23,237,110$ & $23,142,012$ & $5,215,943$ & $28,453,054$ & $28,357,955$ & 3.23 & 3.22 & 3.96 & 3.95 \\
\hline 1985 & 0.05000 & 0.05317 & $23,807,577$ & $23,652,662$ & $5,398,615$ & $29,206,192$ & $29,051,276$ & 3.24 & 3.22 & 3.98 & 3.96 \\
\hline 1986 & 0.05000 & 0.05355 & $24,455,210$ & $24,232,980$ & $5,484,062$ & $29,939,272$ & $29,717,042$ & 3.21 & 3.18 & 3.93 & 3.90 \\
\hline 1987 & 0.05000 & 0.05391 & $25,476,234$ & $25,179,202$ & $5,875,554$ & $31,351,788$ & $31,054,756$ & 3.10 & 3.07 & 3.82 & 3.78 \\
\hline 1988 & 0.05000 & 0.05426 & $26,794,137$ & $26,413,591$ & $6,156,594$ & $32,950,731$ & $32,570,185$ & 3.09 & 3.04 & 3.79 & 3.75 \\
\hline 1989 & 0.05000 & 0.05460 & $28,140,144$ & $27,666,158$ & $6,311,384$ & $34,451,528$ & $33,977,542$ & 3.03 & 2.97 & 3.70 & 3.65 \\
\hline 1990 & 0.05000 & 0.05493 & $29,638,918$ & $29,061,367$ & $6,201,600$ & $35,840,518$ & $35,262,967$ & 2.94 & 2.89 & 3.56 & 3.50 \\
\hline 1991 & 0.05000 & 0.05526 & $31,120,499$ & $30,428,460$ & $6,990,245$ & $38,110,744$ & $37,418,705$ & 2.99 & 2.92 & 3.66 & 3.59 \\
\hline 1992 & 0.05000 & 0.05558 & $32,765,076$ & $31,947,644$ & $7,545,451$ & $40,310,527$ & $39,493,094$ & 3.04 & 2.96 & 3.73 & 3.66 \\
\hline 1993 & 0.05000 & 0.05588 & $34,142,007$ & $33,187,334$ & $7,554,242$ & $41,696,249$ & $40,741,576$ & 3.21 & 3.12 & 3.92 & 3.83 \\
\hline 1994 & 0.05000 & 0.05619 & $35,553,244$ & $34,451,007$ & $7,770,646$ & $43,323,890$ & $42,221,654$ & 3.26 & 3.16 & 3.97 & 3.87 \\
\hline 1995 & 0.05000 & 0.05648 & $37,038,450$ & $35,778,170$ & $7,991,200$ & $45,029,651$ & $43,769,370$ & 3.30 & 3.19 & 4.01 & 3.90 \\
\hline 1996 & 0.05000 & 0.05677 & $38,703,901$ & $37,274,683$ & $8,476,284$ & $47,180,184$ & $45,750,967$ & 3.34 & 3.22 & 4.07 & 3.95 \\
\hline 1997 & 0.05000 & 0.05706 & $40,743,337$ & $39,133,141$ & $8,796,446$ & $49,539,783$ & $47,929,587$ & 3.39 & 3.26 & 4.12 & 3.99 \\
\hline
\end{tabular}

Note: All variables are expresses in 1990 price level. GDP deflator was used to find real M2-. K1 measure follows César das Neves (1994)'s assumptions for the depreciation rate (d1). Variables expressed in $10^{6}$ PTE. 

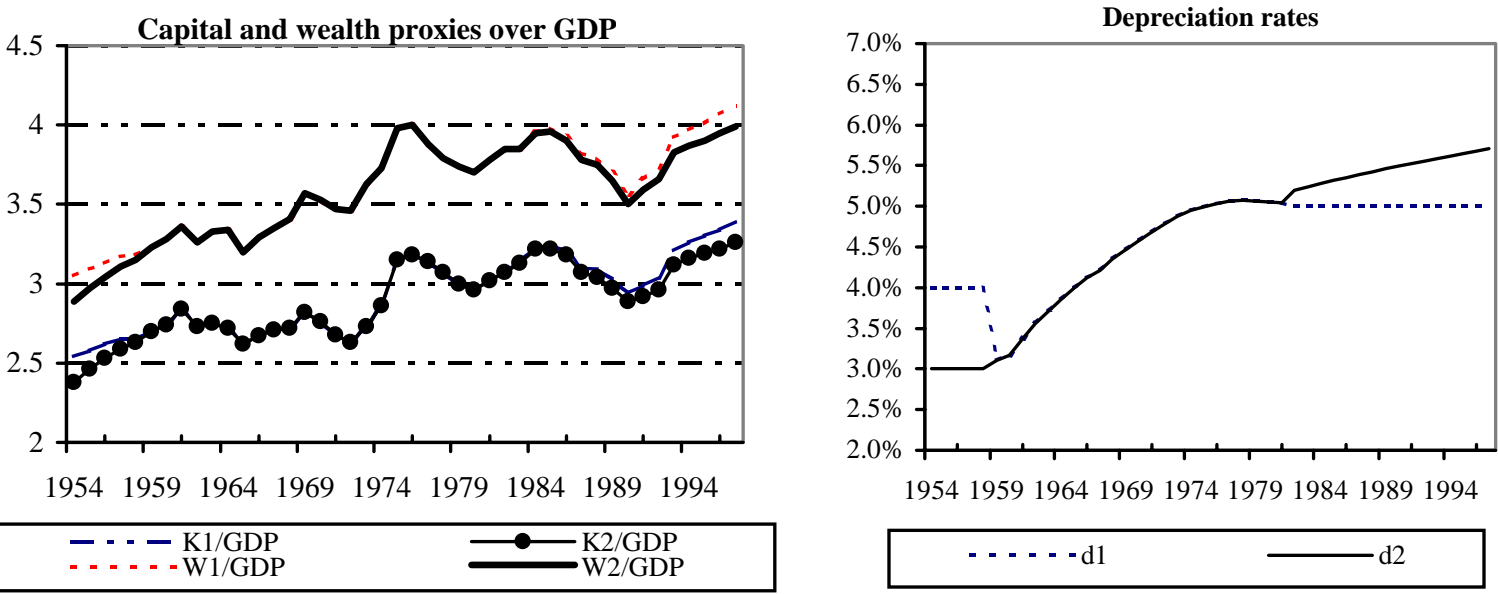

195419591964196919741979198419891994

$\cdots-\cdots-\mathrm{d} 1$ $\mathrm{d} 2$

\section{A comparison with other OECD countries}

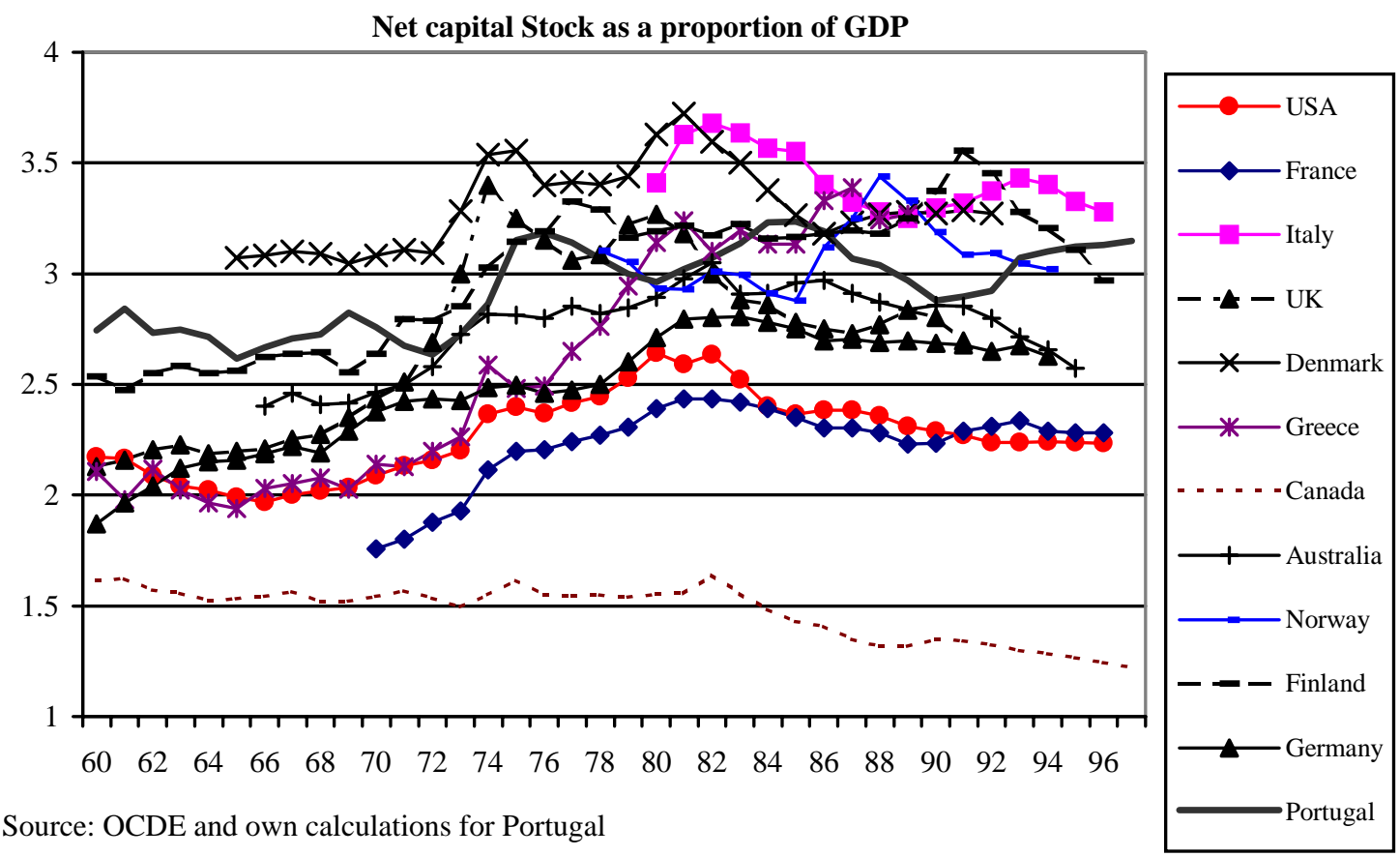




\section{Net Capital Stock as proportion to GDP}

1989

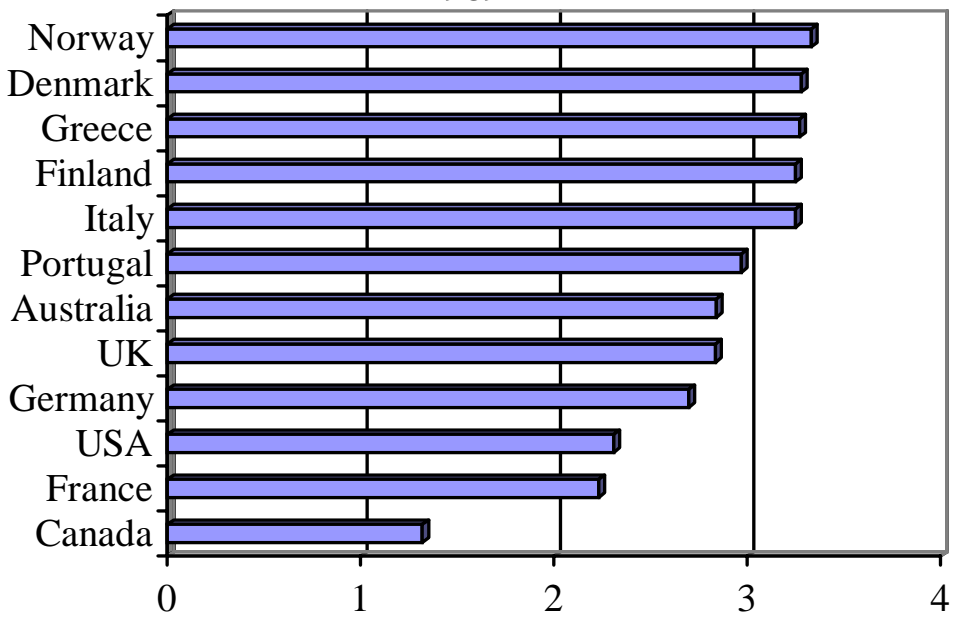

Source: OECD and own calculations for Portugal.

As can be seen from the graphs above the calculated capital-GDP ratio for Portugal occupies an intermediate position. It should however be mentioned that the absolute level of our calculations is much the result of the imposition of the departing point of a 2.7 ratio for 1959, found by Emanuel (1984). 


\section{ESTUDOSDO G.E.M.F.}

2001

№. 11 Ricardian Equivalence: An Empirical A pplication to the Portuguese E conomy

- Carlos Fonseca M arinheiro

№. 10 A Especificação da Função de Produção M acro-E conómica em E studos de C rescimento E conómico.

- Maria A delaide Duarte e M arta Simões

NNo. 9 E ficácia da A nálise Técnica no M ercado A ccionista Português

- Nuno Silva

No. 8 The Risk Premiums in the Portuguese T reasury Bills Interest Rates: Estimation by a

cointegration method

- José Soares da Fonseca

№. 7 Principais factores de crescimento da economia portuguesa no espaço europeu

- Maria A delaide Duarte e M arta Simões

N‥ 6 Inflation Targeting and Exchange Rate C 0-ordination

- Fernando Alexandre, John D riffill e Fabio Spagnolo

No. 5 Labour M arket Transition in Portugal, Spain, and Poland: A Comparative Perspective - Paulino Teixeira

N ‥ 4 Paridade do Poder de Compra e das Taxas de Juro: U m estudo aplicado a três países da UEM

- António Portugal Duarte

№. 3 Technology, Employment and W ages

- John T. Addison e Paulino Teixeira

$\mathrm{N}$ ․ 2 H uman capital investment through education and economic growth. A panel data analysis based on a group of Latin A merican countries

- M aria A delaide Duarte e M arta Simões

N ‥ 1 Risk Premiums in the Porutguese T reasury Bills Interest Rates from 1990 to 1998. An

ARCH M Approach

- José Soares da Fonseca

2000

N ํ. 8 I dentificação de V ectores de C ointegração: A nálise de A lguns E xemplos

- Pedro Miguel Avelino Bação

NNo. 7 I munização e M -quadrado: Q ue relação?

- Jorge C unha

N‥ 6 Eficiência Informacional nos Futuros L isbor 3M

- N uno M. Silva 
No. 5 Estimation of D efault Probabilities $U$ sing Incomplete C ontracts $D$ ata - J. Santos Silva e J. M urteira

N ‥ 4 U n Essaie d'A pplication de la Théorie Q uantitative de la M onnaie à l'économie portugaise, 1854-1998

- João Sousa Andrade

№. 3 Le Taux de C hômage $\mathrm{N}$ aturel comme un Indicateur de Politique E conomique? U ne application à l'économie portugaise - A delaide Duarte e João Sousa Andrade

N‥ 2 La C onvergence Réelle Selon la Théorie de la C roissance: Q uelles Explications pour I'U nion Européenne?

- M arta C ristina N unes Simões

№. 1 Política de E stabilização e Independência dos B ancos C entrais

- João Sousa Andrade

\section{9}

N ․ 9 N ota sobre a E stimação de V ectores de C ointegração com os Programas C A TS in RATS, PCFIM L eEVIEW S

- Pedro Miguel Avelino Bação

N ‥ 8 A A bertura do M ercado de T elecomunicações C elulares ao T erceiro 0 perador: U ma D ecisão Racional?

- Carlos Carreira

N ‥ 7 Is Portugal Really so A rteriosclerotic? Results from a C ross-C ountry A nalysis of Labour A djustment

- John T. Addison e Paulino Teixeira

$\mathrm{N}$ ․ 6 The Effect of Dismissals Protection on E mployment: M ore on a $V$ exed Theme - John T. Addison, Paulino Teixeira e Jean-Luc Grosso

№. 5 A C obertura Estática e D inâmica através do Contrato de Futuros PSI-20. Estimação das Rácios e Eficácia Ex Post e Ex A nte

- H elder Miguel C. V. Sebastião

№. 4 M obilização de Poupança, Financiamento e Internacionalização de C arteiras - João Sousa Andrade

NN. $3 \quad N$ atural Resources and Environment - A delaide D uarte

No. 2 L'A nalyse Positive de la Politique M onétaire - Chistian Aubin

$\mathrm{N}$ ․ 1 E conomias de E scala e de $\mathrm{G}$ ama nos H ospitais Públicos Portugueses: U ma A plicação da Função de C usto V ariável Translog - Carlos Carreira 
№. 11 E quilíbrio M onetário no L ongo e C urto Prazos - U ma A plicação à E conomia Portuguesa - João Sousa Andrade

N ‥ 10 A lgumas 0 bservações Sobre o M étodo da E conomia - João Sousa Andrade

NNo. 9 M udança Tecnológica na Indústria Transformadora: Q ue Tipo de V iés A final? - Paulino Teixeira

N ‥ 8 Portfolio Insurance and B ond M anagement in a V asicek's T erm Structure of Interest Rates - José A lberto Soares da Fonseca

N ‥ 7 Financial Innovation and M oney D emand in Portugal: A Preliminary Study - Pedro M iguel Avelino Bação

NN. 6 The Stability Pact and Portuguese Fiscal Policy: the A pplication of a V AR M odel - Carlos Fonseca M arinheiro

N ‥ 5 A M oeda Ú nica e o Processo de D ifusão da Base M onetária - José A lberto Soares da Fonseca

N ‥ 4 La Structure par Termes et la V olatilité des Taux d'intérêt LISBO R - José A lberto Soares da Fonseca

N ‥ 3 Regras de C omportamento e R eformas M onetárias no N ovo SM I - João Sousa Andrade

No. 2 U m Estudo da Flexibilidade dos Salários: o C aso Espanhol e Português - A delaide D uarte e João Sousa A ndrade

№. 1 M oeda Ú nica e Internacionalização: A presentação do T ema - João Sousa Andrade

1997

№. 9 Inovação e A plicações Financeiras em Portugal - Pedro Miguel Avelino Bação

№. 8 Estudo do E feito Liquidez A plicado à E conomia Portuguesa - João Sousa Andrade

№. 7 An Introduction to C onditional Expectations and Stationarity - Rui Manuel de Almeida

NN 0.6 D efinição de M oeda e E feito B erlusconi - João Sousa Andrade

N ‥ 5 A Estimação do Risco na E scolha dos Portafólios: U ma V isão Selectiva - António Alberto Ferreira dos Santos

N ‥ 4 A Previsão N ão Paramétrica de Taxas de Rentabilidade - Pedro Manuel Cortesão Godinho

N ‥ 3 Propriedades A ssimptóticas de D ensidades - Rui Manuel de Almeida 
№. 2 C o-tntegration and VAR A nalysis of the Term Structure of Interest Rates: an empirical study of the Portuguese money and bond markets - João Sousa Andrade e José Soares da Fonseca

N ‥ 1 Repartição e Capitalização. D uas M odalidades C omplementares de Financiamento das Reformas

- Maria Clara M urteira

\section{6}

№. 8 A C rise e o Ressurgimento do Sistema M onetário E uropeu - Luis Manuel de Aguiar Dias

$\mathrm{N}$ ․ $7 \quad \mathrm{H}$ ousing Shortage and $\mathrm{H}$ ousing Investment in Portugal a Preliminary V iew - Vítor N eves

$\mathrm{N} \cong .6 \mathrm{H}$ ousing, M ortgage Finance and the B ritish E conomy - Kenneth Gibb e Nile Istephan

No. 5 The Social Policy of The European C ommunity, Reporting Information to E mployees, a U.K. perspective: H istorical A nalysis and Prognosis

- Ken Shackleton

No. 4 T Teorema da Equivalência Ricardiana: aplicação à economia portuguesa - Carlos Fonseca M arinheiro

NNo. 30 Teorema da Equivalência Ricardiana: discussão teórica - Carlos Fonseca M arinheiro

№. 2 As taxas de juro no M M I e a Restrição das Reservas 0 brigatórias dos Bancos - Fátima Assunção Sol e José Alberto Soares da Fonseca

№. 1 U ma A nálise de C urto Prazo do C onsumo, do Produto e dos Salários - João Sousa Andrade 